\title{
Zinc phosphate-based nanoparticles as alternatives to zinc oxide in diet of weaned piglets
}

Silvia Kociova ${ }^{1,2}$, Kristyna Dolezelikova $^{1,2}$, Pavel Horky ${ }^{3}$, Sylvie Skalickova ${ }^{3}$, Daria Baholet ${ }^{3}$, Lucie Bozdechova $^{1,2}$, Eva Vaclavkova ${ }^{4}$, Jaroslava Belkova ${ }^{4}$, Pavel Nevrkla ${ }^{5}$, Jiri Skladanka ${ }^{3}$, Tomas Do ${ }^{1}$, Ondrej Zitka ${ }^{1,2}$, Yazan Haddad ${ }^{1,2}$, Pavel Kopel ${ }^{1,6}$, Ludek Zurek ${ }^{1,7}$, Vojtech Adam ${ }^{1,2}$ and Kristyna Smerkova ${ }^{1,2^{*}}$

\begin{abstract}
Background: The high doses of zinc oxide $(\mathrm{ZnO})$ administered orally to piglets for the prevention of diarrhea and increase of growth rate can contaminate pig farms and the surrounding environment. Therefore, there is a need to find a replacement of high doses of dietary $\mathrm{ZnO}$ with an equally effective alternative. In the present study, the effect of two formulations of zinc phosphate-based nanoparticles (ZnA and ZnC NPs) on growth performance, intestinal microbiota, antioxidant status, and intestinal and liver morphology was evaluated. A total of 100 weaned piglets were randomly divided into 10 equal groups with the base diet (control) or the base diet supplemented with ZnA, ZnC, or ZnO at concentrations 500, 1000, and $2000 \mathrm{mg}$ Zn per kilogram of diet. Supplements were given to animals for 10 days. Fecal samples were collected on day 0,5, 10 and 20. At the end of the treatment (day 10), three piglets from each group were sacrificed and analyzed.
\end{abstract}

Results: Comparing to that of control, the significantly higher piglet weight gain was observed in all piglet groups fed with ZnA $(P<0.05)$. Differences in the total aerobic bacteria and coliform counts in piglet feces after NPs supplementation compared to that of control and $\mathrm{ZnO}$ groups were also found $(P<0.05)$. The majority of aerobic culturable bacteria from the feces represented Escherichia (28.57-47.62\%), Enterococcus (3.85-35.71\%), and Streptococcus (3.70-42.31\%) spp. A total of 542 Escherichia coli isolates were screened for the virulence genes STa, STb, Stx2, F4, and F18. The substantial occurrence of E. coli virulence factors was found on day 5, mainly in fimbrillary antigen and thermostable toxins, except for piglets fed by $\mathrm{ZnC}$. Zn treatment decreased $\mathrm{Zn}$ blood levels in piglets fed with ZnO and ZnA (500 mg/kg) and increased in ZnC (2000 mg/kg) compared to that of control $(P<0.05)$. The antioxidant status of piglets was affected only by ZnA. While some changes in the liver and the intestinal morphology of piglets with NPs were observed, none were serious as reflected by the normal health status and increased weigh gain performance.

\footnotetext{
* Correspondence: kristyna.smerkova@mendelu.cz

'Department of Chemistry and Biochemistry, Mendel University in Brno, Zemedelska 1, CZ-613 00 Brno, Czech Republic

${ }^{2}$ Central European Institute of Technology, Brno University of Technology, Purkynova 123, CZ-612 00 Brno, Czech Republic

Full list of author information is available at the end of the article
}

C C The Author(s). 2020 Open Access This article is licensed under a Creative Commons Attribution 4.0 International License, which permits use, sharing, adaptation, distribution and reproduction in any medium or format, as long as you give appropriate credit to the original author(s) and the source, provide a link to the Creative Commons licence, and indicate if changes were made. The images or other third party material in this article are included in the article's Creative Commons licence, unless indicated otherwise in a credit line to the material. If material is not included in the article's Creative Commons licence and your intended use is not permitted by statutory regulation or exceeds the permitted use, you will need to obtain permission directly from the copyright holder. To view a copy of this licence, visit http://creativecommons.org/licenses/by/4.0/ The Creative Commons Public Domain Dedication waiver (http://creativecommons.org/publicdomain/zero/1.0/) applies to the data made available in this article, unless otherwise stated in a credit line to the data. 
(Continued from previous page)

Conclusions: Our results indicate that ZnA NPs have a positive effect on the piglet growth performance even at the lowest concentration. The prevalence of $E$. coli virulence factors was lowest in pigs supplemented with $Z n C$. Zinc phosphate-based nanoparticles may be an effective alternative to $\mathrm{ZnO}$.

Keywords: Antioxidant status, Diet, E. coli STa, STb, Stx2, F4, F18, Fecal coliforms, Microbiota

\section{Background}

Zinc is an essential trace element for animals as it plays an important role in nutrition, growth, and immunity. Due to its efficiency and a reasonable price, zinc in the form of zinc oxide $(\mathrm{ZnO})$ has been commonly used in high doses (2000 to $3000 \mathrm{mg} / \mathrm{kg}$ diet) for weaned piglets as an alternative to antibiotics to prevent intestinal inflammation and increase weight gain $[1,2]$. However, starting in 2022 in the European Union, zinc use in such high concentrations will be banned $[3,4]$. This is because zinc requirements for piglets are only 80 to 100 $\mathrm{mg} / \mathrm{kg}$ [5] and therefore high medication doses of zinc are not utilized by the animals and can result in environmental contamination [6, 7]. In fact, it has been shown that pig farm sites have high concentrations of zinc in the soil [8]. Moreover, the high zinc doses $(2500 \mathrm{mg} / \mathrm{kg}$ diet) affect the intestinal microbiota, and there is also evidence for co-selection of the antibiotic resistance traits $[9,10]$.

Zinc nanoparticles (ZnNPs) can be an excellent alternative to high doses of zinc, in terms of higher pharmacokinetic efficiency, especially when used against coliform bacteria in other mammals [11]. ZnNPs (450 $\mathrm{mg} / \mathrm{kg}$ diet) significantly reduced the Escherichia coli population in the small and large intestine in weaned piglets. Furthermore, it lead to much lower excretion of zinc in the feces in comparison to that of the same dose of $\mathrm{ZnO}$ [12]. It has been demonstrated that ZnNPs in pig nutrition can reduce the zinc use up to $60 \%$ while maintaining the same positive effect on the intestinal microbiome [13]. Nevertheless, there are many questions remaining about the safety of nanoparticles and their metabolites for animals and their fate and the effect on the environment. For example, it has been shown that some nanoparticles may impair the growth of aquatic plants [14]. Zinc is also a strong antioxidant related to the protection of porcine dermis and its derivatives $[15,16]$.

Based on our previous work, where four types of ZnNPs were characterized and tested on rats [11], the two types of antibacterial zinc phosphate-based NPs were studied as alternatives to $\mathrm{ZnO}$ in the diet of weaned piglets. ZnNPs positively influenced the growth performance of piglets compared to that of control. Moreover, the effect of ZnNPs on the intestinal microbiome, antioxidant markers, intestinal and liver morphology, and the diarrhea occurance of growing pigs was evaluated.

\section{Materials and methods \\ Chemicals}

All chemicals were purchased from Sigma Aldrich (St. Louis, MO, USA) and Penta (Prague, Czech Republic) of p.a. purity, unless noted otherwise. The $\mathrm{pH}$ was measured using inoLab Level 3 (Wissenschaftlich-Technische Werkstatten GmbH; Weilheim, Germany). Deionised water underwent demineralisation by reverse osmosis using the instruments Aqua Osmotic 02 (Aqua Osmotic, Tisnov, Czech Republic) and then it was subsequently purified using Millipore RG (Millipore Corp., Waltham, MA, USA) - 18 M' $\Omega$ MilliQ water.

\section{ZnNPs synthesis}

The phosphate-based ZnNPs were synthesized according to the procedure published in our previous study [11]. Briefly, ZnA NPs were prepared by dissolving of $\mathrm{Zn}\left(\mathrm{NO}_{3}\right)_{2} \cdot 6 \mathrm{H}_{2} \mathrm{O}(44.6 \mathrm{~g})$ in $500 \mathrm{~mL}$ of milliQ water and heating to $60{ }^{\circ} \mathrm{C}$. Then, $13.2 \mathrm{~g}$ of $\left(\mathrm{NH}_{4}\right)_{2} \mathrm{HPO}_{4}$ dissolved in $200 \mathrm{~mL}$ of milliQ water was added. After $2 \mathrm{~h}$ of stirring, the mixture was made up to $1000 \mathrm{~mL}$ with milliQ water. The $\mathrm{ZnC}$ NPs were prepared by dissolving of $\mathrm{Zn}\left(\mathrm{NO}_{3}\right)_{2} \cdot 6 \mathrm{H}_{2} \mathrm{O}(30 \mathrm{~g})$ in $500 \mathrm{~mL}$ of milliQ water and heating to $60{ }^{\circ} \mathrm{C}$. Then, $13.3 \mathrm{~g} \mathrm{Na}_{4} \mathrm{P}_{2} \mathrm{O}_{7}$ dissolved in 200 $\mathrm{mL}$ of milliQ water was added. After $2 \mathrm{~h}$ of stirring, the mixture was made up to $1000 \mathrm{~mL}$ with milliQ water.

\section{Animal experiment}

The experiment was performed with the approval of the Ethics Committe at the Faculty of AgriSciences, Mendel University in Brno, Czech Republic in accordance with the Act No. 246/1992 Coll. on the protection of animals against cruelty.

Proposed experiment was conducted on an accredited experimental farm of the Research Institute of Animal Production in Prague (Czech Republic). The experiment was carried out on weaned piglets divided into 10 groups with 10 animals in each group. The sex ratio in the group was 50:50 (castrates:females). The first group served as control, where zinc intake was not manipulated in the diet. The second, third, and fourth group were supplemented with zinc in the form of $\mathrm{ZnO}$ at a dose of 500, 1000, and $2000 \mathrm{mg}$ of $\mathrm{Zn}$ equivalent per kilogram of diet, respectively. The fifth, sixth and 
seventh groups of piglets were supplemented with $\mathrm{ZnA}$ nanoparticles at a dose of 500, 1000 and $2000 \mathrm{mg}$ of $\mathrm{Zn}$ equivalent per kilogram of diet, respectively. The last tested supplementation was $\mathrm{ZnC}$ nanoparticles, which were added to the eighth, ninth, and tenth group of piglets at doses of 500, 1000 and $2000 \mathrm{mg}$ of $\mathrm{Zn}$ equivalent per kilogram of diet, respectively.

The experiment started on the weaning day of the piglets (day 28 of the animal age), and the $\mathrm{Zn}$ feeding lasted for 10 days. Different forms of zinc were mixed into the piglet mixture (Table 1 and Table S1). The total content of phosphorus in the diet was $6.49 \mathrm{~g} / \mathrm{kg}$ - calculated by the feed program Agrokonzulta (Czech Republic). The piglets had a feed and water available ad libitum. The animal husbandry complied with Decree No. 208/2004 Coll. (Decree on minimum standards for the protection of farm animals).

Before starting the experiment, piglets were weighed, and $10 \mathrm{~mL}$ of blood from vena jugularis externa was collected and aliquotted in two tubes by a veterinarian. At the end of the feeding stage of the experiment (10 days), body weight and blood collection were conducted as described above. Three piglets (females) were sacrificed from each group, and the liver and the small intestine (1/3 of the duodenum) were collected for histological analysis. Generally, females have more sensitive antioxidant system than males. Moreover, females are more susceptible to acute liver injury from xenobiotics than males [17-19]. The samples were fixed in a $10 \%$ formalin solution. The sacrificing of piglets was performed with the Exagon ${ }^{\circ}$ anaesthetic $(400 \mathrm{mg} / \mathrm{mL})$. Piglets were given general anesthesia with a combination of Xylazine ${ }^{\circ}$ and Ketamine ${ }^{\circ}$. Remaining piglets were weighed again at the end of the experiment on day 20 .

Table 1 Composition of the diet

\begin{tabular}{ll}
\hline Component & Quantity, \% \\
\hline Barley seed & 41.2 \\
Grain selvico test & 25.0 \\
Wheat seed & 17.4 \\
Dried poultry blood & 4.5 \\
Trace mineral-vitamin premix ${ }^{a}$ & 3.8 \\
Wheat bran & 3.0 \\
Fish meal 70\% & 2.6 \\
Molcolac & 1.0 \\
Formic acid & 1.0 \\
Fish fat & 0.53 \\
\hline
\end{tabular}

${ }^{a}$ Supplied per kilogram diet as feed basis: vitamin $A, 5000 \mathrm{IU}$; vitamin $D_{3}, 800$ IU; vitamin E, $30 \mathrm{IU}$; vitamin $\mathrm{K}_{3}, 1.0 \mathrm{mg}$; biotin, $0.05 \mathrm{mg}$; folic acid, $0.3 \mathrm{mg}$; niacin, $10 \mathrm{mg}$; $D$-pantothenic acid, $10 \mathrm{mg}$; riboflavin, $3.6 \mathrm{mg}$; thiamine, $1.0 \mathrm{mg}$; pyridoxin, $1.5 \mathrm{mg}$; choline, $800 \mathrm{mg} ; \mathrm{Zn}\left(\mathrm{ZnSO}_{4}\right), 120 \mathrm{mg}$; Fe $\left(\mathrm{FeSO}_{4}\right), 125 \mathrm{mg}$; $\mathrm{Cu}$ $\left(\mathrm{CuSO}_{4} \cdot 5 \mathrm{H}_{2} \mathrm{O}\right), 15 \mathrm{mg} / \mathrm{kg} ; \mathrm{Mn}\left(\mathrm{MnSO}_{4} \cdot \mathrm{H}_{2} \mathrm{O}\right), 10 \mathrm{mg} / \mathrm{kg}$; ( $(\mathrm{Kl}), 0.15 \mathrm{mg} ; \mathrm{Se}$ $\left(\mathrm{Na}_{2} \mathrm{SeO}_{3}\right), 0.2 \mathrm{mg}$; enramycin, $20 \mathrm{mg}$; chlortetracycline, $50 \mathrm{mg}$

\section{Quantitative and qualitative analysis of the microbiome} in piglet feces

Fresh fecal samples were collected from individual piglets immediately before the start of the zinc treatment (day 0 ) and then on day 5, 10 and 20. The fresh feces were sampled into sterile collection tubes, kept on wet ice and processed within $4 \mathrm{~h}$. Determination of the total aerobic microorganisms and the total coliforms count was performed. In addition, qualitative identification of the major bacterial groups was conducted. Both analyses were carried out separately for each sample. The fecal samples were homogenized in sterile $0.85 \%$ saline $(1: 9 w /$ $v$ ), and the homogenate was then serially diluted. Subsequently, $1.0 \mathrm{~mL}$ of diluted suspension was pour plated on the Plate Count agar (PCA) and MacConkey agar (Sigma-Aldrich) in duplicates. All colonies from PCA and from MacConkey agar were counted after $24 \mathrm{~h}$ at $37^{\circ} \mathrm{C}$. The results are expressed as $\log (\mathrm{CFU} / \mathrm{g})$ of feces. For identification of the major groups of bacteria, the fecal samples were applied on selective agars designed for growth of E. coli and coliforms (HiCrome Chromogenic Coliform HiCynth agar, Himedia, India), streptococci, and enterococci (Columbia blood agar with Streptococcus selective supplement, Oxoid, UK; Mitis Salivarius agar, Sigma-Aldrich). Representative individual colonies were picked from each agar plate and streaked on $5 \%$ blood sheep agar and incubated at $37^{\circ} \mathrm{C}$ for $24 \mathrm{~h}$. Individual isolates were identified by the matrix-assisted laser desorption/ionization time-of-flight mass spectrometer (MALDI-TOF MS) Bruker ultrafleXtreme (Bruker Daltonik GmbH, Bremen, Germany) using MALDI BioTyper $^{\text {ru }}$ Compass Explorer 4.1.90 analysis software equipped with MBT 8468 MPS library. Bacterial isolates were then stored at $-80^{\circ} \mathrm{C}$ for further analysis.

\section{E. coli virulence factors}

Confirmed E. coli isolates were screened for five virulence factors $(F 18, F 4, S T a, S T b, S t x 2)$ and one housekeeping gene (uidA) by multiplex PCR. Briefly, a loopfull of each isolate was transferred to $200 \mu \mathrm{L}$ of sterile distilled water in a $1.5 \mathrm{~mL}$ sterile microcentrifuge tube. Cells were lysed by boiling for $10 \mathrm{~min}$, incubated on ice for $5 \mathrm{~min}$, and centrifuged for $2 \mathrm{~min}$ at $13500 \times \mathrm{g}$. Three microliters of the supernatant were used per PCR reaction. The following E. coli strains were used as positive controls: E. coli 13502 (for Stx2 and F18), E. coli 10423 (for STa, STb, and F18) and E. coli 11803 (for STb and F4). E. coli 7929 (from the Czech Collection of Microorganisms, Brno) was used as a non-pathogenic (negative) control. The mixture for PCR reaction $(25 \mu \mathrm{L})$ was composed of $12.5 \mu \mathrm{L}$ Q5 Hot Start High Fidelity 2X Master Mix (NEB, USA), $0.3 \mu \mathrm{L}$ of primers for $\operatorname{Stx} 2$ (VT2, $10 \mu \mathrm{mol} / \mathrm{L})$ and $F 18(10 \mu \mathrm{mol} / \mathrm{L}), 0.46 \mu \mathrm{L}$ of $S T b$ primers $(10 \mu \mathrm{mol} / \mathrm{L})$ and $0.63 \mu \mathrm{L}$ of $S T a$ primers $(10 \mu \mathrm{mol} / \mathrm{L})$, 
$6.14 \mu \mathrm{L}$ of deionized water and $3 \mu \mathrm{L}$ of lysate. The second reaction was performed for F4 and uidA. The mixture for PCR reaction $(25 \mu \mathrm{L})$ was composed of $12.5 \mu \mathrm{L}$ Q5 Hot Start High Fidelity 2X Master Mix (NEB, USA), $0.625 \mu \mathrm{L}$ of $F 4$ primers $(10 \mu \mathrm{mol} / \mathrm{L}), 1 \mu \mathrm{L}$ of uidA primers $(10 \mu \mathrm{mol} / \mathrm{L}), 6.25 \mu \mathrm{L}$ of deionized water and $3 \mu \mathrm{L}$ of lysate. Primers used in this study are described in Table 2. Amplification was done on a Mastercycler nexus (Eppendorf, Germany). Cycling conditions were as follows: $90^{\circ} \mathrm{C}$ for $5 \mathrm{~min}, 35$ cycles of $90^{\circ} \mathrm{C}$ for $1 \mathrm{~min}$, $61{ }^{\circ} \mathrm{C}$ for $1 \mathrm{~min}, 72^{\circ} \mathrm{C}$ for $1 \mathrm{~min}$, followed by $72^{\circ} \mathrm{C}$ extension for $10 \mathrm{~min}$ and $4{ }^{\circ} \mathrm{C}$ hold. The PCR products were visualized by gel electrophoresis using $1.5 \%$ agarose (Sigma Aldrich, USA).

\section{Glutathione peroxidase analysis}

The activity of glutathione peroxidase (GPx) was carried out according to the protocol of RANSEL (Randox, United Kingdom). Briefly, GPx catalyzed the glutathione (GSH) oxidation by peroxide to its oxidized form (GSSG). In the presence of glutathione reductase and NADPH, GSSG is converted to GSH and simultaneously the NADPH is oxidized to NADP+ which is accompanied by a change in absorbance maximum. The analysis was carried out on the spectrophotometer Secomam S.500P (Secomam, USA) with absorbance wavelength set to $340 \mathrm{~nm}$.

\section{Malondialdehyde analysis}

Determination of malondialdehyde (MDA) was carried out using the spectrophotometer Agilent Cary 60 (Agilent, USA). MDA is one of the secondary products of lipid peroxidation. At elevated temperature, a red complex with thiobarbituric acid (TBA) forms in an acidic environment. The absorbance of the resulting color complex MDA-TBA is measured at three wavelengths of $485 \mathrm{~nm}, 532 \mathrm{~nm}$, and $560 \mathrm{~nm}$.

\section{Zinc detection}

Zinc concentration was determined by the atomic absorption spectrometer with flame and electrothermal atomization Varian AAS DUO $280 \mathrm{Z}+240 \mathrm{FS}$ - FAAS flame technology (Agilent, USA).

\section{Statistical analysis}

The bacterial counts were analysed using IBM SPSS Statistics 21 (IBM Corporation, Armonk, New York, USA) and the differences with $P<0.05$ were considered as significant. Zinc concentration (0, 500, 1000 and $2000 \mathrm{mg} /$ $\mathrm{kg})$, treatment group $(\mathrm{ZnA}, \mathrm{ZnC}$ and $\mathrm{ZnO})$ and time period $(0,5,10$ and 20 days) were treated as categorical data types throughout all tests. Extreme (far) outliers of the total and coliform counts were removed according to boxplots of treatment groups and $\mathrm{Zn}$ concentration in each time period. Extreme outliers were values outside the $3 \times$ interquartile range, which most likely resulted from errors in pipetting and dilutions. Near outliers (outside the $1.5 \times$ interquartile range) were retained.

In each $\mathrm{Zn}$ treatment group, analysis of variance (ANOVA) test was used to detect significant differences in microbial growth based on $\mathrm{Zn}$ concentrations. Pairwise comparisons based on the weighted average of "Studentized" ranges were done using the Dunnett's C post hoc test for unequal variances. The paired T-test was used to study significant differences in microbial growth between time periods and day zero.

The comparison between treatment groups and $\mathrm{ZnO}$ group was performed using independent sample T-test and Mann Whitney test. Due to the frequent significance in Levene test of equal variances and inconsistencies in T-test results, the non-parametric Mann Whitney test results were considered more reliable in this part of the study.

To study the significance of $\mathrm{Zn}$ treatments and dosage as risk factors for diarrhea, adjusted odds ratios (OR)

Table 2 Primers used virulence factor detection

\begin{tabular}{|c|c|c|c|}
\hline Virulence factor & Primer sequence $\left(5^{\prime} \rightarrow 3^{\prime}\right)$ & PCR product size, bp & Reference \\
\hline \multirow[t]{2}{*}{ F18 } & TGGTAACGTATCAGCAACTA & 313 & [20] \\
\hline & ACTTACAGTGCTATTCGACG & & \\
\hline \multirow[t]{2}{*}{ F4 } & GCCTGGATGACTGGTGATTT & 709 & [21] \\
\hline & TCTGACCGTTTGCAATACCC & & \\
\hline \multirow[t]{2}{*}{ STa } & CAACTGAATCACTTGACTCTT & 158 & [20] \\
\hline & TTAATAACATCCAGCACAGG & & \\
\hline \multirow[t]{2}{*}{$\mathrm{STb}$} & TGCCTATGCATCTACACAAT & 113 & [20] \\
\hline & CTCCAGCAGTACCATCTCTA & & \\
\hline \multirow[t]{2}{*}{ Stx2 (VT2) } & GTIITCTTCGGTATCCTATTCC & 484 & [22] \\
\hline & GATGCATCTCTGGTCATTGTATTAC & & \\
\hline \multirow[t]{2}{*}{ uidA } & TGTTACGTCCTGTAGAAAGCCC & 153 & [23] \\
\hline & AAAACTGCCTGGCACAGCAATT & & \\
\hline
\end{tabular}


were calculated by binary logistic regression. The event of diarrhea was used as dependent variable with binary $0 / 1$ values. Covariates were added via $a \times b$ entry method to calculate cross-adjusted OR. Confidence interval (CI) for OR were calculated at $95 \%$.

The data for antioxidant status and $\mathrm{Zn}$ levels were analyzed using STATISTICA.CZ, version 12.0 (Czech Republic). The results were expressed as a mean from all samples \pm standard deviation. Statistical significance was determined by examining the basic differences among groups using ANOVA and Scheffé's method for all parameters. The differences with $P<0.05$ were considered as significant.

\section{Results}

\section{Piglet growth}

Piglets had a mean weight between 6.0 and $8.1 \mathrm{~kg}$ in different groups at the start of the experiment (Table 3 ). The control group had a weight gain of $2.0 \mathrm{~kg}$ after 20 days. At a dose of $500 \mathrm{mg} \mathrm{Zn/kg} \mathrm{diet,} \mathrm{the} \mathrm{highest} \mathrm{weight}$ increase was observed in the group of piglets with $\mathrm{ZnA}$ NPs $(3.7 \mathrm{~kg}$ ). Piglets fed a $\mathrm{Zn}$ dose of $1000 \mathrm{mg} / \mathrm{kg}$ diet had the highest weight increase in the ZnA group (3.7 $\mathrm{kg})$. At the dose of $\mathrm{Zn} 2000 \mathrm{mg} / \mathrm{kg}$ diet, the highest weight increase was also observed in the $\mathrm{ZnA}$ group $(4.4 \mathrm{~kg})$. Overall, significantly higher weight gains $(P<$ 0.05 ) were observed in $\mathrm{ZnA}$ piglet groups compared to that of the control group at all $\mathrm{Zn}$ concentrations. The increase was $2.5 \mathrm{~kg}, 2.7 \mathrm{~kg}$, and $3.4 \mathrm{~kg}$ for $\mathrm{Zn}$ dose 500 , 1000 , and $2000 \mathrm{mg} \mathrm{Zn/kg} \mathrm{diet,} \mathrm{respectively.} \mathrm{Also,} \mathrm{group}$ $\mathrm{ZnC}$ (dose $2000 \mathrm{mg} / \mathrm{kg}$ ) and $\mathrm{ZnO}(1000 \mathrm{mg} / \mathrm{kg})$ showed a significant increase $(P<0.05)$ in weight compared to that of control. Significant differences in weight gain were not observed between groups supplemented with zinc nanoparticles $(\mathrm{ZnA}, \mathrm{ZnC})$ and $\mathrm{ZnO}$. Body weight gain was highest in the ZnA $2000 \mathrm{mg} / \mathrm{kg}$ group $(4.4 \mathrm{~kg}$ ). The lowest body weight gain was observed in the control group $(2.0 \mathrm{~kg})$.

\section{Effect of $\mathrm{Zn}$ treatments on aerobic bacteria and coliforms counts}

The counts of total aerobic bacteria determined in piglet feces over 20 days are shown in Fig. 1. The overall average counts were $7.71 \times 10^{8} \mathrm{CFU} / \mathrm{g}$ feces for $\mathrm{ZnA}$, $2.76 \times 10^{9} \mathrm{CFU} / \mathrm{g}$ for $\mathrm{ZnC}, 1.06 \times 10^{9} \mathrm{CFU} / \mathrm{g}$ for $\mathrm{ZnO}$, and $4.28 \times 10^{9} \mathrm{CFU} / \mathrm{g}$ for the control group. Compared with the control group, the significant difference $(P<0.05)$ was determined for ZnA (500 and $1000 \mathrm{mg} /$ $\mathrm{kg}), \mathrm{ZnC}(500,1000$, and $2000 \mathrm{mg} / \mathrm{kg})$, and $\mathrm{ZnO}(500$ and $1000 \mathrm{mg} / \mathrm{kg}$ ) at day 0 (Fig. 1a). Then, the significant decrease $(P<0.05)$ was observed at day 20 (Fig. 1d) in the case of $\mathrm{ZnA}(500,1000$, and $2000 \mathrm{mg} / \mathrm{kg}$ ) and $\mathrm{ZnO}$ (500 and $2000 \mathrm{mg} / \mathrm{kg}$ ) compared with the control group. When comparing the NPs treatment with $\mathrm{ZnO}$, the significant mean difference was found between $\mathrm{ZnA}$ and $\mathrm{ZnO}$ at day $5(1000 \mathrm{mg} / \mathrm{kg})$ and day $20(2000 \mathrm{mg} / \mathrm{kg})$ when $\mathrm{ZnA}$ counts were significantly higher $(P=0.021)$ on $5^{\text {th }}$ day and conversely significantly lower $(P=0.026)$ on $20^{\text {th }}$ day (Fig. 1b, d). Between $\mathrm{ZnC}$ and $\mathrm{ZnO}$, the significant differences were found at day 5, 10 and 20 (Fig. 1b, c, d). Specifically, ZnC (1000 and $2000 \mathrm{mg} / \mathrm{kg}$ ) showed a significant decrease $(P<0.001)$ in counts at day 5 , while on the $10^{\text {th }}$ day of treatment, all concentrations of $\mathrm{ZnC}$ caused significantly increased bacterial growth $(P<0.01)$. The significantly higher $(P=0.01)$ counts for $\mathrm{ZnC}(1000$ $\mathrm{mg} / \mathrm{kg}$ ) were also observed on day 20 compared to $\mathrm{ZnO}$.

The change of coliforms counts in piglet feces during the treatment is presented in Fig. 2. The overall mean coliforms counts were calculated as $1.36 \times 10^{7} \mathrm{CFU} / \mathrm{g}$ feces for $\mathrm{ZnA}, 8.71 \times 10^{6} \mathrm{CFU} / \mathrm{g}$ for $\mathrm{ZnC}, 6.42 \times 10^{7}$ $\mathrm{CFU} / \mathrm{g}$ for $\mathrm{ZnO}$, and $7.76 \times 10^{7} \mathrm{CFU} / \mathrm{g}$ for the control group. The coliform concentration was significantly lower $(P<0.05)$ in $\mathrm{ZnC}$ group $(1000$ and $2000 \mathrm{mg} / \mathrm{kg})$ at day 0 compared to the control (Fig. 2a). Interestingly, the significant increase $(P<0.05)$ of coliforms was observed in $\mathrm{ZnA}(1000 \mathrm{mg} / \mathrm{kg}$, day 10) and $\mathrm{ZnC}(2000 \mathrm{mg} /$ $\mathrm{kg}$, day 20) groups in comparison with the control (Fig. 2c, d). When comparing $\mathrm{ZnO}$ with NPs treatment, the difference in coliforms growth was significant on all collection days. The coliforms counts were significantly higher for $\mathrm{ZnO}$ group in comparison to that in $\mathrm{ZnA}$ group $1000(P=0.035)$ and $2000 \mathrm{mg} / \mathrm{kg}(P=0.002)$; and also ZnC group $1000(P=0.001)$ and $2000 \mathrm{mg} / \mathrm{kg}$ $(P=0.003)$ at day 0 (Fig. 2a). In contrast, on day 5 (Fig. $2 b)$, the coliform concentration significantly increased $(P=0.027)$ for $\mathrm{ZnA}(1000 \mathrm{mg} / \mathrm{kg})$. ZnC treatment $(1000$

Table 3 Piglet weight during the experiment

\begin{tabular}{|c|c|c|c|c|c|c|c|c|c|c|}
\hline \multirow[t]{2}{*}{ Day } & \multirow[t]{2}{*}{ Control } & \multicolumn{3}{|c|}{500 mg/kg } & \multicolumn{3}{|c|}{1000 mg/kg } & \multicolumn{3}{|c|}{2000 mg/kg } \\
\hline & & $\mathrm{ZnO}$ & $\mathrm{ZnA}$ & $\mathrm{ZnC}$ & $\mathrm{ZnO}$ & ZnA & $\mathrm{ZnC}$ & $\mathrm{ZnO}$ & $\mathrm{ZnA}$ & $\mathrm{ZnC}$ \\
\hline 0 & $6.6 \pm 1.3$ & $7.1 \pm 0.4$ & $7.4 \pm 0.9$ & $6.0 \pm 0.9$ & $7.9 \pm 1.2$ & $7.6 \pm 1.7$ & $6.8 \pm 1.8$ & $7.0 \pm 0.9$ & $7.6 \pm 1.5$ & $8.1 \pm 0.9$ \\
\hline 10 & $7.7 \pm 1.0$ & $8.6 \pm 1.1$ & $8.6 \pm 1.1$ & $8.0 \pm 1.1$ & $9.0 \pm 1.4$ & $7.5 \pm 1.3$ & $9.1 \pm 1.7$ & $8.6 \pm 1.1$ & $8.9 \pm 1.5$ & $10.3 \pm 0.9^{*}$ \\
\hline 20 & $8.6 \pm 1.5$ & $9.9 \pm 1.1$ & $11.1 \pm 0.9^{*}$ & $9.2 \pm 1.1$ & $11.5 \pm 0.9^{*}$ & $11.3 \pm 1.0^{*}$ & $9.8 \pm 1.0$ & $9.9 \pm 1.3$ & $12.0 \pm 1.8^{*}$ & $10.9 \pm 1.0$ \\
\hline WG & $2.0 \pm 0.7$ & $2.8 \pm 1.4$ & $3.7 \pm 0.8^{*}$ & $3.2 \pm 0.7$ & $3.6 \pm 0.8^{*}$ & $3.7 \pm 1.6$ & $3.0 \pm 0.8$ & $2.9 \pm 0.9$ & $4.4 \pm 1.0^{*}$ & $2.8 \pm 0.9$ \\
\hline
\end{tabular}

WG weight gain (difference between average weight on day 0 and day 20)

*indicates significant differences $(P<0.05)$ between the control and the treated group 

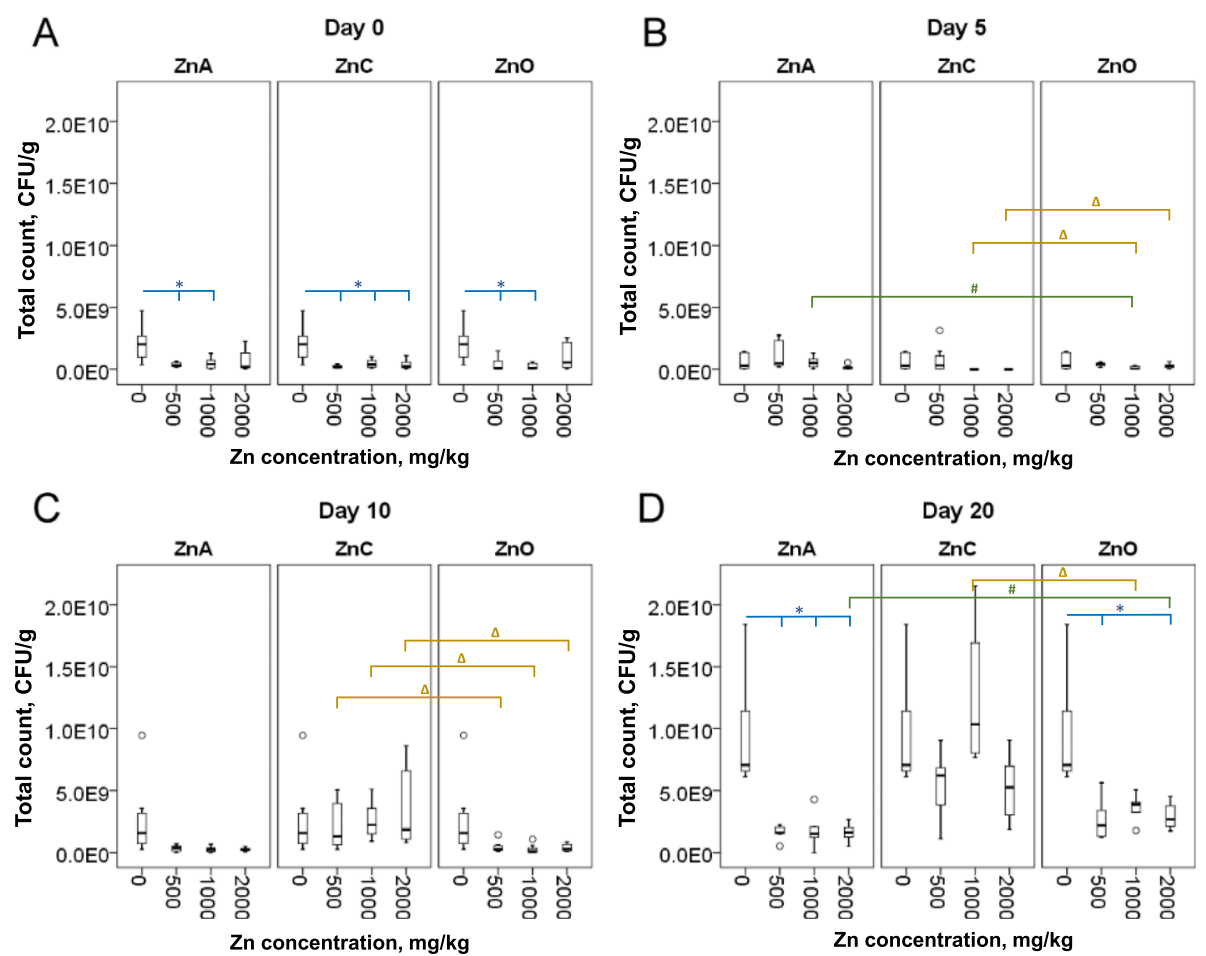

Fig. 1 Total counts of aerobic bacteria at day 0 (a) and after 5 days (b), 10 days (c) and 20 days (d) of Zn treatment. Boxes represent Q1 and Q3 quartiles with median bar while T-whiskers represent 95\% confidence intervals of 6-10 individuals. ${ }^{*}$ indicates significant differences $(P<0.05)$ between group without treatment ( 0 ) and groups with $\mathrm{Zn}$ treatment. \# indicates significant differences $(P<0.05)$ between $\mathrm{ZnA}$ and $\mathrm{ZnO}$ group (the equal $\mathrm{Zn}$ concentrations were compared). $\Delta$ indicates significant differences $(P<0.05)$ between $\mathrm{ZnC}$ and $\mathrm{ZnO}$ group (the equal $\mathrm{Zn}$ concentrations were compared)

and $2000 \mathrm{mg} / \mathrm{kg})$ caused a significant decrease $(P<0.05)$ of the coliforms concentration at day 5 of treatment compared to that of $\mathrm{ZnO}$. At day 10 of the treatment (Fig. 2c), the similar pattern to that on day 5 was found. $\mathrm{ZnA} \quad(500 \mathrm{mg} / \mathrm{kg})$ exhibited significant increase $(P=$ 0.017 ) of coliforms; however, the counts significantly decreased $(P<0.01)$ in the case of $\mathrm{ZnC}$ treatment $(1000$ and $2000 \mathrm{mg} / \mathrm{kg}$ ). And vice versa, compared to $\mathrm{ZnO}$ the coliforms growth was significantly higher $(P=0.014)$ at day 20 (Fig. 2d) for $\mathrm{ZnC}(2000 \mathrm{mg} / \mathrm{kg}$ ).

The temporal comparison showed significant changes between day 0 and the rest of the days in all treatments (Fig. S1, note: controls were removed from paired Ttest). During ZnA treatment (Fig. S1A, B), paired-mean total CFUs was significantly lower $(P=0.038)$ in day 10 compared to day 0 by $2.79 \times 10^{8} \mathrm{CFUs}$. Whereas pairedmean total CFUs was significantly higher $(P<0.001)$ on day 20 compared to day 0 by $1.30 \times 10^{9}$ CFUs. Pairedmean coliform counts were significantly lower $(P=$ 0.003 ) in day 20 compared to day 0 by $1.23 \times 10^{7}$ CFUs. Moreover, significant positive moderate correlation $\left(R^{2}=0.449, P=0.021\right)$ was observed in coliforms between day 0 and day 5. After $\mathrm{ZnC}$ treatment (Fig. S1C, $D)$ paired-mean total counts were significantly higher $(P<0.001)$ on day 10 compared to day 0 by $2.25 \times 10^{8}$
CFUs. The significantly higher $(P<0.001)$ counts were also observed in day 20 compared to day 0 by $6.72 \times 10^{9}$ CFUs. In contrast, the coliforms counts were significantly lower $(P<0.001)$ on day 10 compared to day 0 by $7.61 \times 10^{6}$ CFUs and significant reduction $(P=0.005)$ was found on day 20 compared to day 0 by $7.65 \times 10^{6}$ CFUs. In $\mathrm{ZnO}$ treatment (Fig. S1E, F) paired-mean total counts were significantly higher $(P<0.001)$ on day 20 compared to day 0 by $2.53 \times 10^{9}$ CFUs. Coliform counts were significantly lower $(P=0.03)$ on day 5 compared to day 0 by $1.60 \times 10^{8}$ CFUs and significantly lower $(P=$ $0.006)$ as well on day 10 compared to day 0 by $2.25 \times 10^{8}$ CFUs.

\section{Zn treatment and dosage as risk factors for piglet diarrhea}

To further investigate the role of $\mathrm{Zn}$ treatments and dosage as risk factors for piglet diarrhea, binary logistic regression was used for calculating cross-adjusted OR. Interestingly, the increase in $\log _{10} \mathrm{CFU}$ of coliforms (cross-adjusted with either $\mathrm{Zn}$ treatment or concentration) was significantly more associated with diarrhea events in most cases compared to total counts $\log _{10} \mathrm{CFU}$ (see Additional file Table S2). 

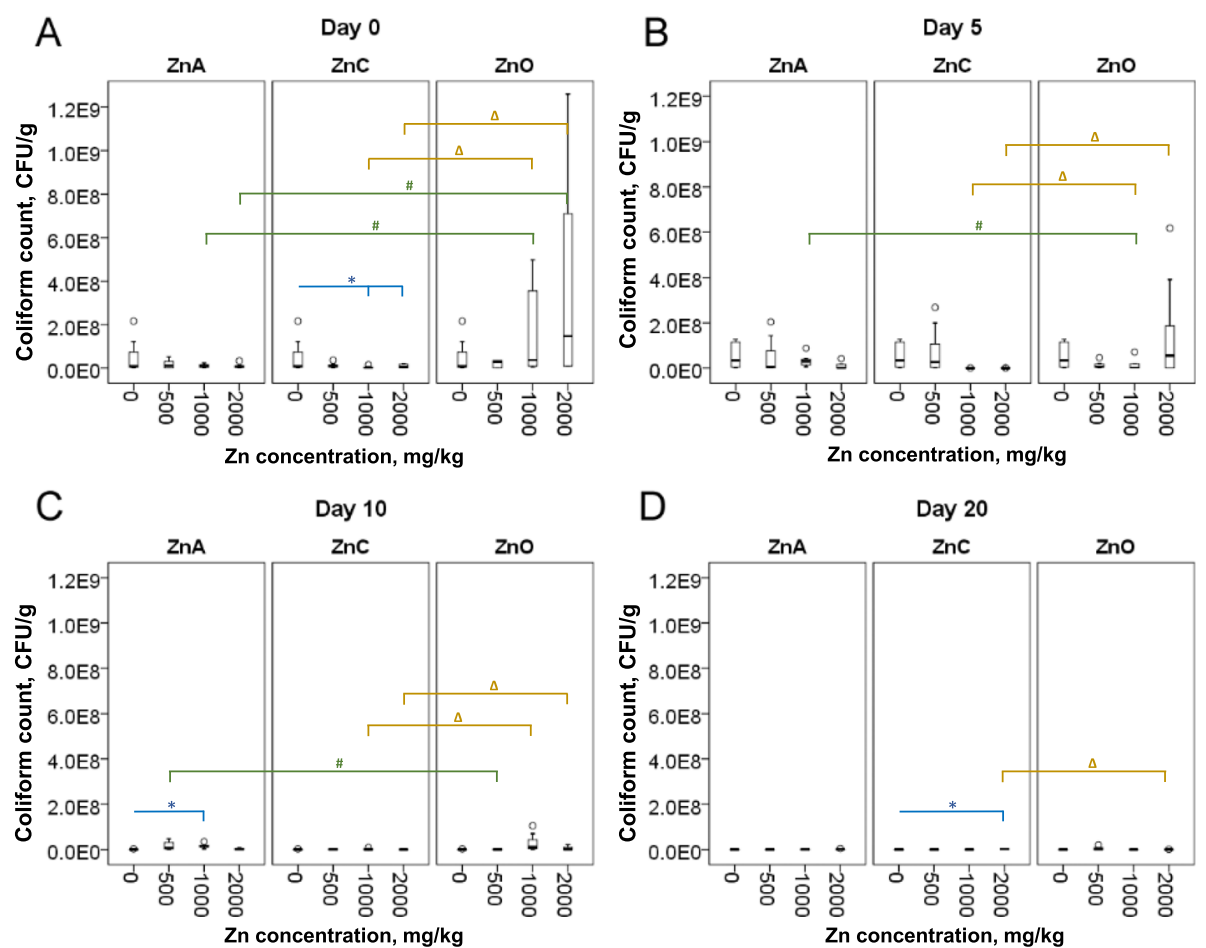

Fig. 2 Counts of coliforms at day 0 (a) and after 5 days (b), 10 days (c) and 20 days (d) of $Z n$ treatment. Boxes represent Q1 and Q3 quartiles with median bar while T-whiskers represent 95\% confidence intervals of $6-10$ individuals. ${ }^{*}$ indicates significant differences $(P<0.05)$ between group without treatment $(0)$ and groups with $\mathrm{Zn}$ treatment. \# indicates significant differences $(P<0.05)$ between $\mathrm{ZnA}$ and $\mathrm{ZnO}$ group (the equal $\mathrm{Zn}$ concentrations were compared). $\Delta$ indicates significant differences $(P<0.05)$ between $\mathrm{ZnC}$ and $\mathrm{ZnO}$ group (the equal $\mathrm{Zn}$ concentrations were compared)

Based on Zn concentrations, total counts $\log _{10} \mathrm{CFU}$ crossadjusted with 1000 and $2000 \mathrm{mg} / \mathrm{kg}$ at day 5 significantly increased the risk of diarrhea by $1.814(P=0.002)$ and 1.622 $(P=0.012)$ folds, respectively, compared to that of the control group. There was no significant risk of diarrhea for other $\mathrm{Zn}$ concentrations cross-adjusted with total $\log _{10} \mathrm{CFU}$. According to treatment types, total $\log _{10} \mathrm{CFU}$ cross-adjusted with $\mathrm{ZnA}$ at day 5 significantly increased the risk of diarrhea by 1.448 folds per increments of $\log _{10} \mathrm{CFU}$ units $(P=0.006)$. There was no significant risk of diarrhea in remaining treatment types cross-adjusted with total $\log _{10} \mathrm{CFU}$. According to $\mathrm{Zn}$ concentration, coliform $\log _{10} \mathrm{CFU}$ cross-adjusted with most $\mathrm{Zn}$ concentrations at all times significantly increased the risk of diarrhea by 1.628-2.918 folds, except for $\log _{10} \mathrm{CFU}$ cross-adjusted with $500 \mathrm{mg} / \mathrm{kg}$ at day 0 , and also 500 and $2000 \mathrm{mg} / \mathrm{kg}$ at day 20 . Based on treatment types, coliform $\log _{10} \mathrm{CFU}$ cross-adjusted with most treatment types at all times significantly increased the risk of diarrhea by 1.804-2.811 folds, except for $\log _{10} \mathrm{CFU}$ cross-adjusted with $\mathrm{ZnC}$ at day $0, \mathrm{ZnO}$ and $\mathrm{ZnC}$ at day 20.

Overall, the risk of diarrhea due to increase in coliform $\log _{10} \mathrm{CFU}$ was highest in $\mathrm{ZnA}$ followed by $\mathrm{ZnC}$, followed by $\mathrm{ZnO}$, and control, except on day 5 where $\mathrm{ZnC}$ and $\mathrm{ZnO}$ treatment showed similar risks. The risk of diarrhea due to an increase in total $\log _{10} \mathrm{CFU}$ was highest in ZnA although it was only significant on day 5 .

Effect of $\mathrm{Zn}$ treatment on the diversity of culturable bacteria The diversity of culturable bacteria was assessed from the same fecal samples taken for evaluation of bacterial concentrations. The results were analyzed as a relative abundance of cultivable bacterial taxa for every piglet group (Fig. 3). Escherichia sp. were present in all piglet groups at all time points. Staphylococci were found in piglet feces from all $\mathrm{ZnO}$ treatment groups. The $\mathrm{ZnA}$ group also showed a higher prevalence of Streptococcus sp. and Lactobacillus sp. Also, Enterococcus, Aerococcus and Corynebacterium taxa were observed in most of the groups and time points to some extent.

On the day 0 , the piglets were weaned and fed with diet containing $\mathrm{ZnO}$ and $\mathrm{ZnNPs}$. At that time, the majority of bacteria belonged to Escherichia (28.57-47.62\%), Enterococcus (3.85-35.71\%), Streptococcus (3.70-42.31\%), Lactobacillus (0-14.71\%) and Corynebacterium (0-27.27\%) taxa, but Staphylococcus, Aerococcus and Proteus taxa were also present in low abundance. On the $10^{\text {th }}$ day of the experiment Lactobacillus sp. (0-50.00\%) increased, moreover, the group with the highest concentration of $\mathrm{ZnC}$ also showed Lactococcus sp. (3.85\%). High abundance 


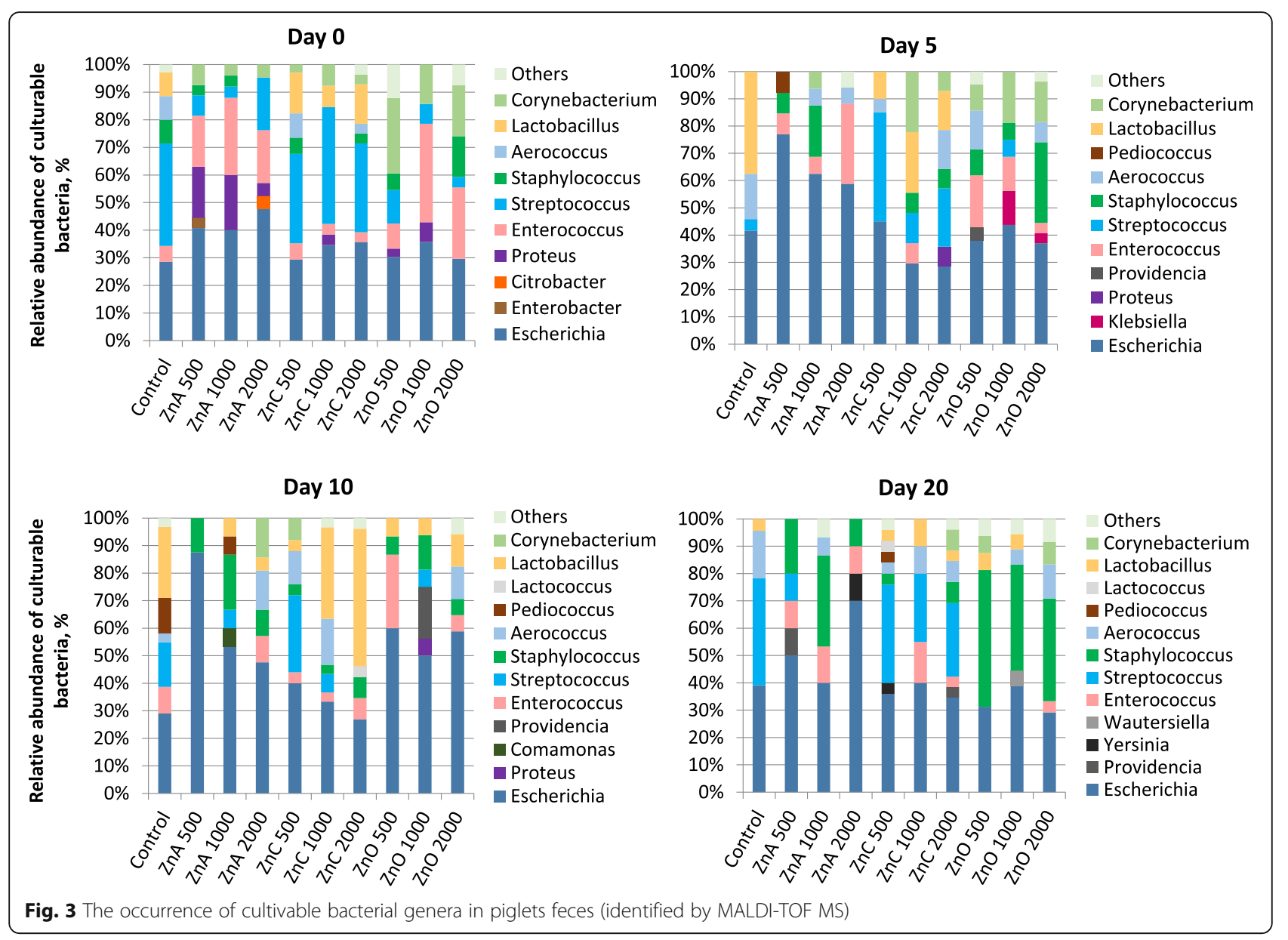

of Staphylococcus sp. (37.50-50.00\%) was found in all $\mathrm{ZnO}$ concentrations on the $20^{\text {th }}$ day. There were two cases of piglets where Yersinia enterocolitica was found ( $\mathrm{ZnA}$ $2000 \mathrm{mg} / \mathrm{kg}$, and ZnC $500 \mathrm{mg} / \mathrm{kg}$ ).

\section{An occurrence of virulence factors in $E$. coli}

The 542 of $E$. coli isolates were screened for five virulence genes (STa, STb, Stx2, F4, F18). These genes have occurred independently or in combinations (Table 4). Only five positive isolates were found at day 0 (two in the control group, two in $\mathrm{ZnC} 500 \mathrm{mg} / \mathrm{kg}$, one in $\mathrm{ZnO} 2000 \mathrm{mg} /$ $\mathrm{kg}$ ). Presence of virulence genes dramatically increased on day 5. All piglets from the control group carried $E$. coli positive for $S T b / F 4$ or $S T b / F 18$. Moreover, one piglet was positive for $F 4$ alone. Similar situation was in piglets group fed with ZnA. All piglets from the group ZnA 1000 and $2000 \mathrm{mg} / \mathrm{kg}$ diet, and nine from $\mathrm{ZnA} 500 \mathrm{mg} / \mathrm{kg}$ diet were positive for virulence factors. The most common genotype was $S T b / F 4$. In the case of $\mathrm{ZnC} 500 \mathrm{mg} / \mathrm{kg}$, there was a high incidence of isolates with virulence genes, mostly $S T b / F 18$. At a dose of $1000 \mathrm{mg} / \mathrm{kg}$ and $2000 \mathrm{mg} / \mathrm{kg}$ of $\mathrm{ZnC}$ and in the group of $\mathrm{ZnO} 500 \mathrm{mg} / \mathrm{kg}$, all piglets were negative for all virulence genes screened. In contrast, in groups of $\mathrm{ZnO} 1000$ and $2000 \mathrm{mg} / \mathrm{kg}$, six piglets were positive, primarily for $S T b / F 4$.

Compared to day 5 , we did not detect any virulence factors in $E$. coli isolates in the control group at day 10 and only two positive piglets were revealed at the day 20. On day 10, there was still relatively high incidence of virulence genes in the group of $\mathrm{ZnA}$ (6 or 7 positive piglets in each group) and that decreased on day 20. Interestingly, the dominant genotype was $S T b / F 18$ comparing to that of day 5 , where the most isolates were positive for $S T b / F 4$. Overtime, an occurrence of virulence genes increased in the group of $\mathrm{ZnC}$. In contrast, in $\mathrm{ZnA}$ group, the isolates with virulence traits decreased. Piglets in the group of $\mathrm{ZnO}$ was mostly positive for $E$. coli with the virulence genes through the entire experiment (Table 4). However, we did not find any correlation between presence of virulence genes and piglet diarrhea.

\section{Effect of $\mathrm{Zn}$ on antioxidant status}

The significant differences after 10 days of treatment in $\mathrm{Zn}$ level and and antioxidant status were observed only in few cases. Compared to the control group, the level of $\mathrm{Zn}$ in blood was even lower in treatements $\mathrm{ZnO}$ and 
Table 4 Virulence genes in E. coli isolated from piglet feces

\begin{tabular}{|c|c|c|c|c|c|c|c|c|c|c|c|c|}
\hline & STa & $S T b$ & St $\times 2$ & $F 4$ & F18 & STb/F4 & STb/F18 & STa/STb & Stx2/F18 & Stx2/STb & $\begin{array}{l}\text { Number of } \\
\text { isolates/positive }\end{array}$ & $\begin{array}{l}\text { Positive piglets/piglets } \\
\text { with diarrhea }\end{array}$ \\
\hline \multicolumn{13}{|l|}{ Day 0} \\
\hline Control & - & 1 & - & - & - & - & 1 & - & - & - & $15 / 2$ & $2 / 0$ \\
\hline ZnA 500 & - & $1 / 1^{a}$ & - & - & - & - & - & 1 & - & - & $16 / 2$ & $2 / 1$ \\
\hline ZnA 1000 & - & - & - & - & - & - & - & - & - & - & $16 / 0$ & - \\
\hline ZnA 2000 & - & - & - & - & - & - & - & - & - & - & $13 / 0$ & - \\
\hline ZnC 500 & - & - & - & - & - & - & - & - & - & - & $15 / 0$ & - \\
\hline ZnC 1000 & - & - & - & - & - & - & - & - & - & - & $12 / 0$ & - \\
\hline ZnC 2000 & - & - & - & - & - & - & - & - & - & - & $10 / 0$ & - \\
\hline ZnO 500 & - & - & - & - & - & - & - & - & - & - & $11 / 0$ & - \\
\hline ZnO 1000 & - & - & - & - & - & - & - & - & - & - & $12 / 0$ & - \\
\hline ZnO 2000 & - & - & - & - & - & 1 & - & - & - & - & $16 / 1$ & $1 / 0$ \\
\hline \multicolumn{13}{|l|}{ Day 5} \\
\hline Control & - & - & - & 1 & - & $5 / 3^{a}$ & $5 / 2^{a}$ & - & - & - & $12 / 11$ & $10 / 5$ \\
\hline ZnA 500 & - & 4 & - & $1 / 1^{a}$ & - & $4 / 1^{\mathrm{a}}$ & 1 & 1 & - & - & $13 / 11$ & $9 / 2$ \\
\hline ZnA 1000 & - & 1 & - & $2 / 1^{a}$ & - & $7 / 4^{a}$ & - & 1 & - & - & $12 / 11$ & $10 / 5$ \\
\hline ZnA 2000 & - & 3 & - & 1 & - & $8 / 3^{a}$ & - & - & - & - & $12 / 12$ & $10 / 3$ \\
\hline ZnC 500 & - & - & - & 1 & - & 2 & $5 / 2^{a}$ & - & - & - & $12 / 8$ & $8 / 2$ \\
\hline ZnC 1000 & - & - & - & - & - & - & - & - & - & - & $12 / 0$ & - \\
\hline ZnC 2000 & - & - & - & - & - & - & - & - & - & - & $11 / 0$ & - \\
\hline ZnO 500 & - & - & - & - & - & - & - & 2 & - & - & $11 / 2$ & $2 / 0$ \\
\hline ZnO 1000 & - & 1 & - & - & 1 & $5 / 3^{a}$ & - & - & - & - & $10 / 7$ & $6 / 3$ \\
\hline ZnO 2000 & - & - & - & - & - & $5 / 3^{a}$ & - & 1 & - & - & $12 / 6$ & $6 / 3$ \\
\hline \multicolumn{13}{|l|}{ Day 10} \\
\hline Control & - & - & - & - & - & - & - & - & - & - & $15 / 0$ & - \\
\hline ZnA 500 & - & - & - & - & - & - & $7 / 3^{a}$ & - & - & - & $8 / 7$ & $7 / 3$ \\
\hline ZnA 1000 & - & - & - & - & - & - & $6 / 2^{a}$ & 1 & - & - & $11 / 7$ & $6 / 2$ \\
\hline ZnA 2000 & - & - & - & - & - & $4 / 1^{a}$ & 3 & 1 & - & - & $13 / 8$ & $6 / 1$ \\
\hline ZnC 500 & - & - & - & - & - & - & - & - & - & - & $22 / 0$ & - \\
\hline ZnC 1000 & - & - & - & - & - & 3 & - & - & - & - & $5 / 3$ & $3 / 0$ \\
\hline ZnC 2000 & - & - & - & - & - & 2 & - & - & - & - & $12 / 2$ & $2 / 0$ \\
\hline ZnO 500 & - & 2 & - & - & - & - & 2 & 4 & - & - & $26 / 8$ & $5 / 0$ \\
\hline ZnO 1000 & - & - & - & - & - & - & 5 & - & - & - & $17 / 5$ & $4 / 0$ \\
\hline ZnO 2000 & - & - & - & - & - & 1 & 2 & - & - & - & $18 / 3$ & $3 / 0$ \\
\hline \multicolumn{13}{|l|}{ Day 20} \\
\hline Control & - & - & - & - & - & - & - & 3 & - & - & $17 / 3$ & $2 / 0$ \\
\hline ZnA 500 & - & 1 & - & - & - & - & - & - & - & - & $6 / 1$ & $1 / 0$ \\
\hline ZnA 1000 & - & 1 & - & - & - & - & - & - & - & - & $7 / 1$ & $1 / 0$ \\
\hline ZnA 2000 & - & - & - & - & - & - & - & $4 / 2^{a}$ & - & - & $11 / 4$ & $2 / 1$ \\
\hline ZnC 500 & - & 2 & - & - & - & - & 2 & - & - & - & $22 / 4$ & $4 / 0$ \\
\hline ZnC 1000 & - & - & - & - & - & 2 & 1 & - & - & - & $15 / 3$ & $3 / 0$ \\
\hline ZnC 2000 & - & - & - & - & - & 2 & $5 / 1^{a}$ & - & - & - & $15 / 7$ & $6 / 1$ \\
\hline ZnO 500 & - & 5 & 2 & - & - & - & - & - & 2 & 1 & $14 / 10$ & $5 / 0$ \\
\hline ZnO 1000 & - & 7 & - & - & 1 & - & - & - & - & - & $14 / 8$ & $4 / 0$ \\
\hline ZnO 2000 & - & - & - & - & - & - & - & 1 & - & - & $11 / 1$ & $1 / 0$ \\
\hline
\end{tabular}




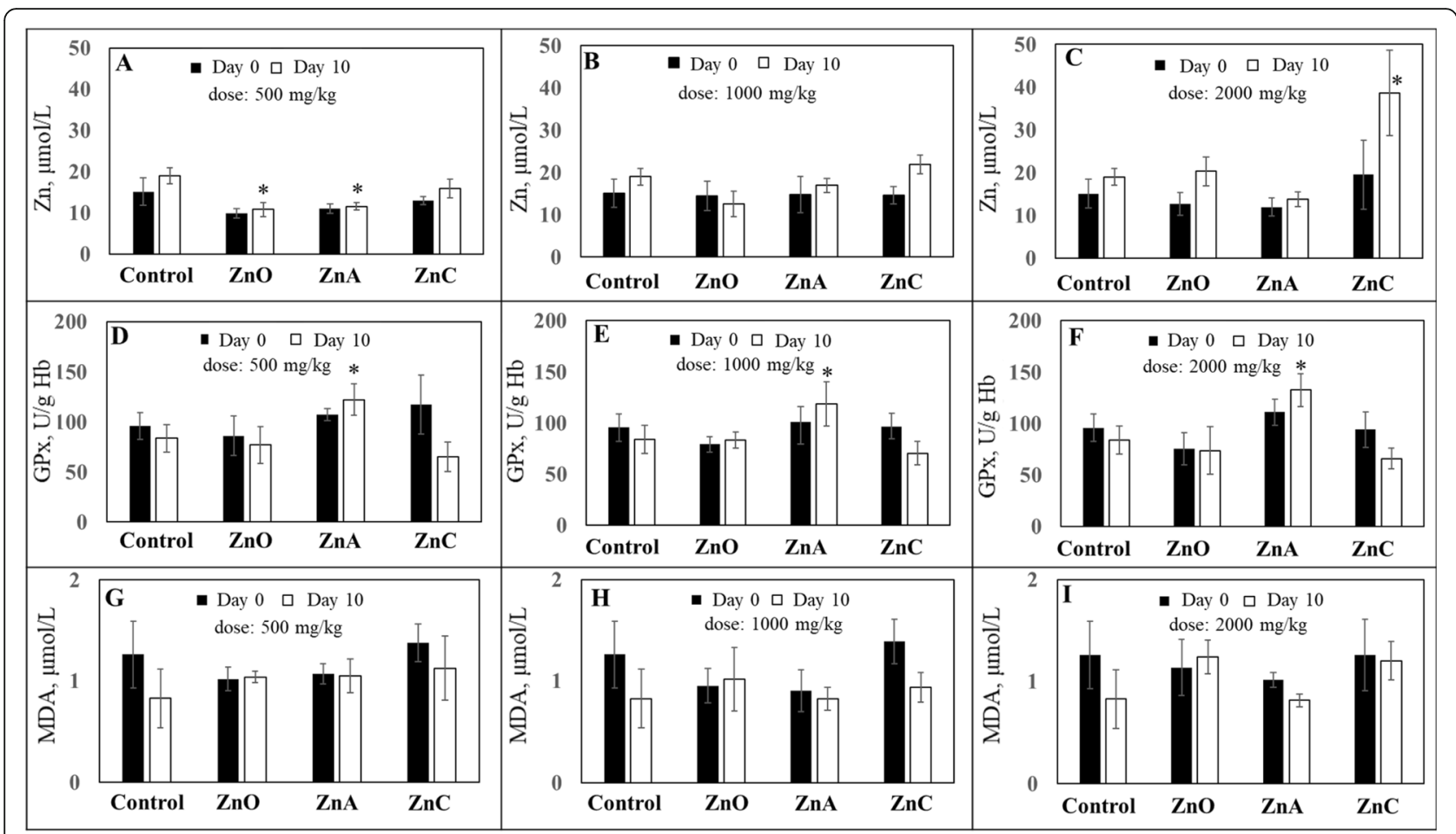

Fig. 4 Concentration of zinc ( $\mathbf{a}, \mathbf{b}, \mathbf{c})$; glutathione peroxidase $(\mathbf{d}, \mathbf{e}, \mathbf{f})$ and malondialdehyde $(\mathbf{g}, \mathbf{h}, \mathbf{i})$ in blood samples. The applied concentrations of zinc were 500,1000 and $2000 \mathrm{mg} / \mathrm{kg}$

$\mathrm{ZnA}$ at the lowest dose. Significantly different $(P<0.05)$ $\mathrm{Zn}$ concentration was detected in piglet blood in the dose of $\mathrm{Zn} 500 \mathrm{mg} / \mathrm{kg}$ diet (Fig. 4a) between groups $\mathrm{ZnO}$ $(8.3 \mu \mathrm{mol} / \mathrm{L})$ and $\mathrm{ZnA}(7.5 \mu \mathrm{mol} / \mathrm{L})$. At a dose of 1000 $\mathrm{mg} / \mathrm{kg}$ diet, no significant differences in zinc levels were observed between the treated and control groups (Fig. 44b). In the highest zinc concentration of $2000 \mathrm{mg} /$ $\mathrm{kg}$ diet (Fig. 4c), a significant increase of $\mathrm{Zn}$ in blood $(P<0.05)$ was observed in the $\mathrm{ZnC}$ group $(19.6 \mu \mathrm{mol} / \mathrm{L})$ compared to that of the control group. The changes in antioxidant status (GPx) was found only at ZnA treated group. GPx significantly increased on day $10(P<0.05)$ in the ZnA group in diets supplemented with 500, 1000, and $2000 \mathrm{mg} \mathrm{Zn} / \mathrm{kg}$ diet compared to that of the control group (Fig. 4d-f). The GPx increase in the ZnA group ranged from 35.0 to $48.8 \mathrm{U} / \mathrm{g} \mathrm{Hb}$. No significant differences were observed in any other groups (Fig. 4d-f). MDA production was not significantly affected by $\mathrm{Zn}$ treatment or concentration in any piglet group (Fig. 4g-i).

\section{Effect of $Z n$ on intestinal and liver morphology}

Effects of ZnNPs and $\mathrm{ZnO}$ treatments on intestinal and liver morphology are shown in Figs. 5 and 6. In the control group, small intestinal inflammations were observed with enlarged spots coinciding with the villi (Fig. 5a). Villlus atrophy occurred only sporadically with a number of Brunner's glands and malabsorption syndrome was diagnosed. Minimal dystrophic changes were found in liver samples (Fig. 6a). The group ZnA showed chronic enteritis with plaque focal atrophy (Figs. 5b, h) and the malabsorption syndrome. The villi were enlarged and deformed (Fig. 5e). Cuticle and goblet cell showed normal distribution. Liver parenchyma was affected by congestive and full-area dystrophy with portobiliary dilution (Figs. 6b, $\mathrm{e}, \mathrm{h})$. The small intestine of the $\mathrm{ZnC}$ treated group exhibited inflammatory and atrophic changes, cuticle was in norm (Fig. 5f, i). Mild enteritis and massive incidence of goblet cells have been identified in $\mathrm{ZnC}$ treated group at a dose of $500 \mathrm{mg} / \mathrm{kg}$ (Fig. 5c). Congestive and dystrophic liver parenchyma (Fig. 6c) as well as dilution of portobilis (Fig. 6f, i) were also noticed. A group treated with $\mathrm{ZnO}$ showed changes in the structure manifested by a large number of goblet cells and chronic inflammation without marked alteration of villi (Fig. $5 \mathrm{~d}, \mathrm{~g}$, j). The liver parenchyma in piglets fed with $\mathrm{ZnO}$ (Fig. 6d, g) showed chronic inflammation with marked congestion. A full-area glycogen hepatophilia with portobilitary dilatation was observed in the group treated with $\mathrm{ZnO}$ at a dosage of $2000 \mathrm{mg} / \mathrm{kg}$ (Fig. 6j).

\section{Discussion}

Zinc (in the form of $\mathrm{ZnO}$ ) is absorbed in the small intestine by simple diffusion and via specific transporters. Zinc enters the small intestinal mucosal cells by binding 


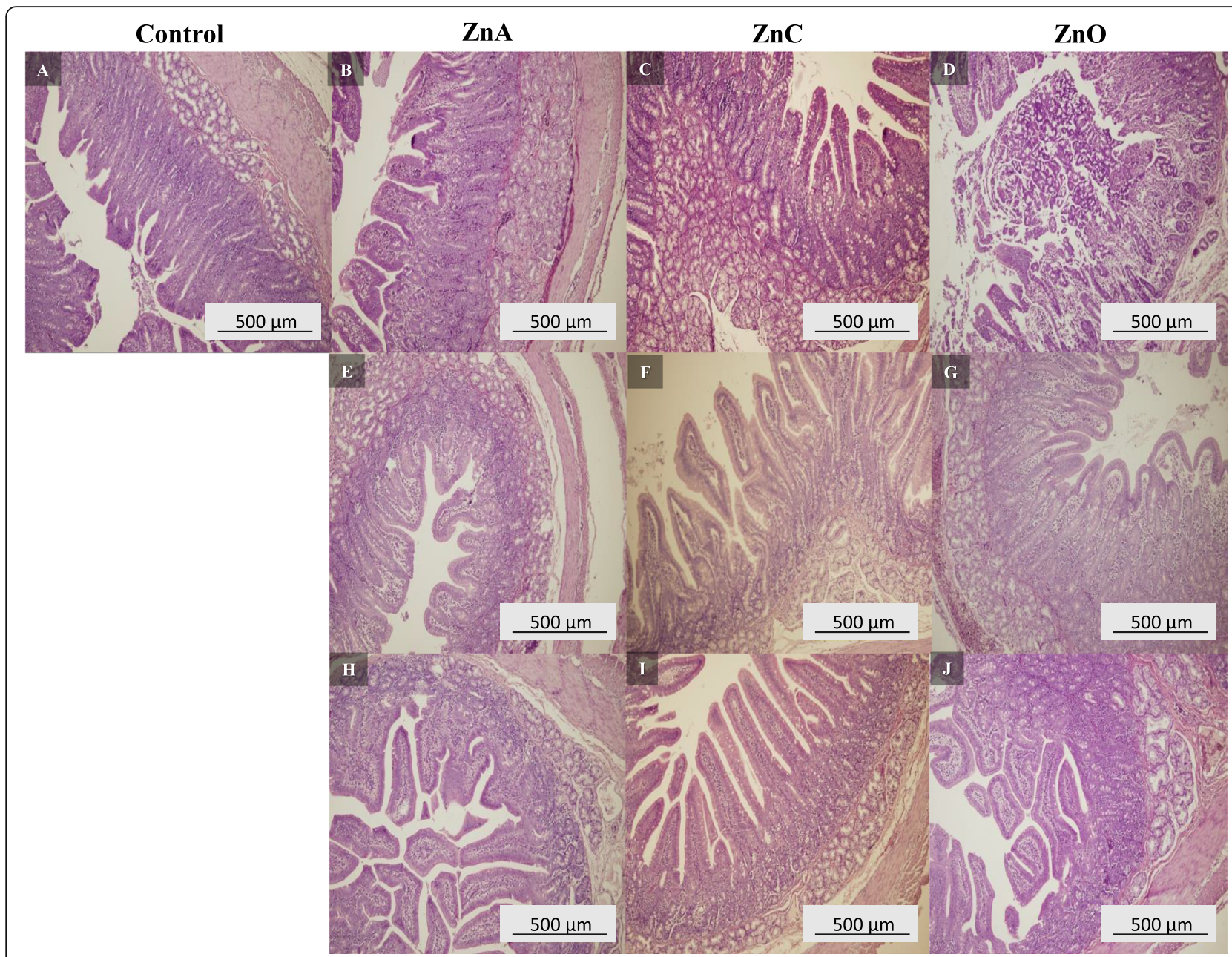

Fig. 5 Histological analysis of piglets small intestine. Control (a), ZnA 500 mg/kg (b), ZnC 500 mg/kg (c), ZnO 500 mg/kg (d), ZnA 1000 mg/kg (e), ZnC 1000 mg/kg (f), ZnO 1000 mg/kg (g), ZnA 2000 mg/kg (h), ZnC 2000 mg/kg (i), ZnO 200 mg/kg (j)

to histidine, cysteine, and prostaglandins. Inside the intestinal mucosal cell, $\mathrm{Zn}$ is bound to the protein metallothionein [24]. Zinc NPs have a higher solubility in the gastrointestinal tract comparing to that of $\mathrm{ZnO}$, and this results in greater antibiotic effect leading to reduction in diarrhea and higher weight gain [12]. The synthesis and characterization of novel hydrogen phosphate-based $\mathrm{ZnA}$ and diphosphate-based ZnC NPs were described in our previous work. Moreover, the antibacterial potential and the effect on the microbiota of rats and their overall health was demonstrated [11]. In addition to body weight increase, $\mathrm{Zn}$ NPs are able to positively affect the feed conversion ratios [25]. It has been shown that a dose of $\mathrm{Zn}$ (as $\mathrm{ZnO}$ ) of $1200 \mathrm{mg} / \mathrm{kg}$ diet is sufficient to improve intestinal integrity and consequently increase the weight gain [26]. In our study, a significant positive effect of $\mathrm{ZnA}$ in all concentrations was observed on the weight of weaned piglets. In the dose of $500 \mathrm{mg} / \mathrm{kg}$ and $1000 \mathrm{mg} / \mathrm{kg}$ of diet, the increment was $3.7 \mathrm{~kg}$, which is comparable with $\mathrm{ZnO}$ in the dose of $1000 \mathrm{mg} / \mathrm{kg}$ of diet.
The highest weight gain, $4.4 \mathrm{~kg}$, was in the group of piglets supplemented with $\mathrm{ZnA}$ in the dose of $2000 \mathrm{of} \mathrm{mg} /$ $\mathrm{kg}$ diet. The use of $\mathrm{ZnA}$ in all concetrations approximately doubles weight increments when compared to that of control. This does not fully correlate with the results of a study by Fernandes and colleagues, where the weight of piglets was not affected by $\mathrm{Zn}$ dose (from 800 to $2500 \mathrm{mg} / \mathrm{kg}$ diet) in the form of $\mathrm{ZnO}$ during 21 to 35 days [27]. Wang et al. [13] also demonstrated that $\mathrm{ZnO}$ or ZnNPs (size $30 \mathrm{~nm}$ ) in the dose of $3000 \mathrm{mg} / \mathrm{kg}$ diet did not show a significant influence on piglets weight. The body weight gain ranged from 2.54 to $3.09 \mathrm{~kg}$ during the experiment [13]. However, our results show a significant increase of weight in piglets fed with $\mathrm{ZnO}$ in the dose $1000 \mathrm{mg} / \mathrm{kg}$ of diet compared to that of control. In another study, encapsulated zinc was tested at levels of 800 (21 to 35 days of age) and 500 (36 to 49 days of age) $\mathrm{mg} / \mathrm{kg}$ diet. An average weight loss of $0.37 \mathrm{~kg}$ compared to classical $\mathrm{ZnO}$ was observed at a dose of 2500 $\mathrm{mg} \mathrm{Zn} / \mathrm{kg}$ diet. A $35.8 \%$ increase in diarrhea incidence 


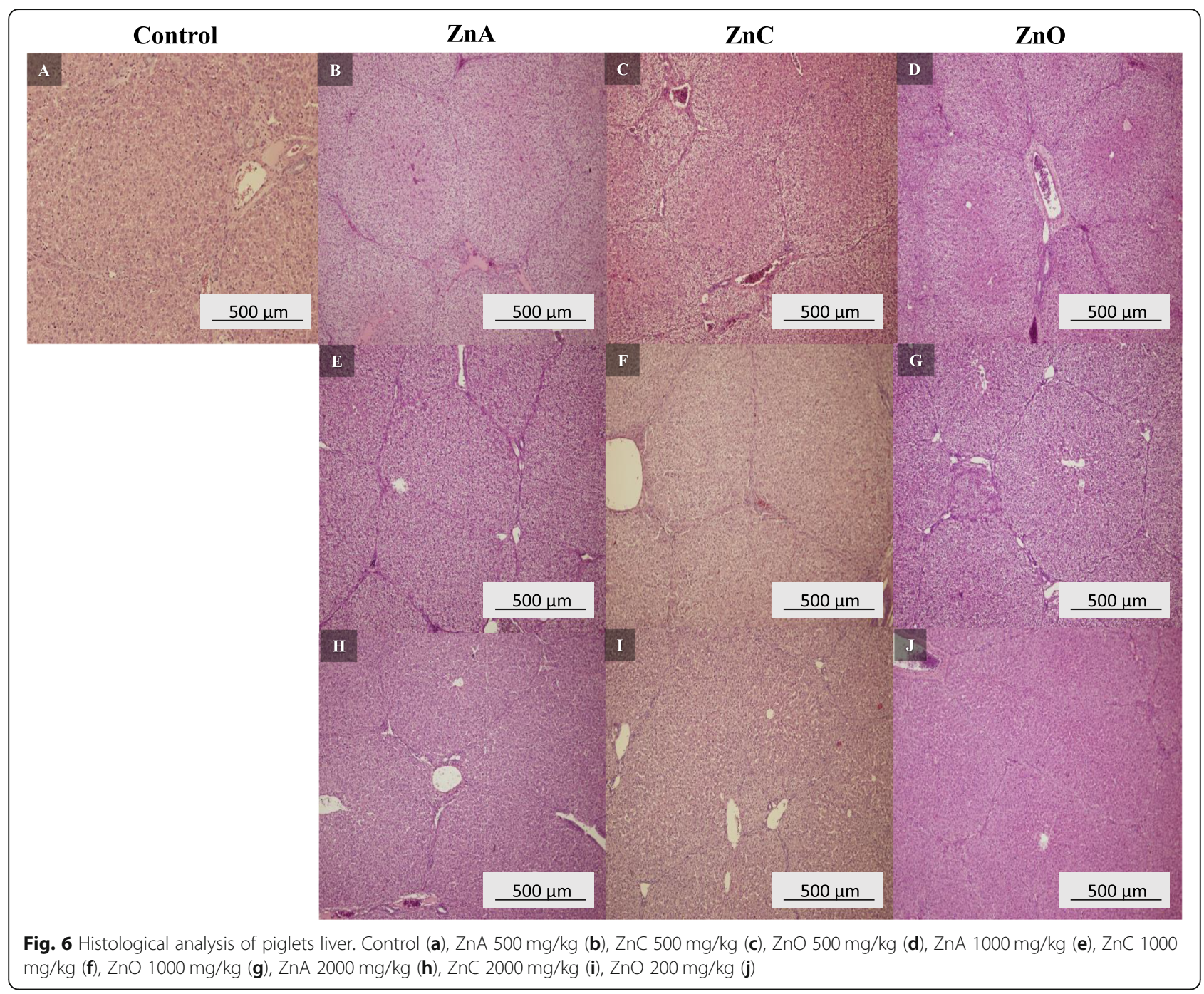

was observed in the zinc encapsulated group [27]. In our study, we observed the opposite trend, all treatments with $\mathrm{ZnNPs}$ led to greater weight gain comparing to that of the control group with the largest increase of weight gain in the $\mathrm{ZnA}$ group. It is known that weaning of piglets causes a decrease in the level of zinc and this may exacerbate problems at weaning (diarrhea, weight reduction) [28].

Understanding the composition of the microbial community and its functional capacity during weaning is important for pig production since bacteria play an important role in swine health and growth performance. The total number of culturable bacteria in control, $\mathrm{ZnO}$ and ZnNPs groups showed increasing trend of CFUs per gram of feces. Piglets overcome stress caused by dietary changes during the weaning transition through a gut microbiome shift and these results emphasize the importance of the early-life microbiota [29]. Coliform bacteria, milkfermenting bacteria, and bacteria including Streptococcus sp. and Enterococcus sp. are found in the gastrointestinal tract after weaning commences [30]. Zinc feed additives therefore seem to have no effect on the presence of the most frequent representatives of coliforms and milkfermenting bacteria in the gastrointestinal microbiome. There were no obvious differences in the bacterial diversity between piglets on $\mathrm{ZnO}$ and $\mathrm{ZnNPs}$, indicating they have similar bactericidal effects. The majority of the bacteria were represented by Escherichia, Enterococcus, Streptococcus, Lactobacillus and Corynebacterium taxa; however, Staphylococcus and Proteus sp. were also present. Nevertheless, there were two piglet cases, where Yersinia enterocolitica was also found, one of which was presented with bloody diarrhea (day 20, $2000 \mathrm{mg} \mathrm{ZnA}$ per $\mathrm{kg}$ of feed). In this case, the presence of heat-stable enterotoxin in E. coli isolated from the same sample was also confirmed. Another strain of $Y$. enterocolitica was found in the $\mathrm{ZnC}$ group (day 20,500 mg/kg), where the genes for heat-stable enterotoxin and F18 fimbriae in E. coli were 
detected as well. Nevertheless, this piglet did not show any diarrhea symptoms. It is, therefore, evident that the presence of potentially pathogenic bacteria does not necessary lead to diarrhea. However, it is well known that a minimal number of bacterial cells are required for colonization and pathogenicity [31, 32], and our data show quantitative evidence of the role of coliforms in risk of diarrhea (see Additional file Table S2). In most of the studied Zn treatments and concentrations, the increase in coliform CFU has indeed been shown to increase the likelihood of diarrhea. Additionally, it is important to add that diarrhea is also influenced by the overall health status, and it is therefore individual for each animal [33]. For example, Colombo et al. demonstrated that $\mathrm{ZnO}$ NPs affect the intestinal barrier. The in vitro barrier integrity could be compromised depending on the size and concentration of NPs and the proinflammatory cytokine release was found [34]. Moreover, the oxidative damage of intestinal epithelial cells by $\mathrm{ZnO}$ NPs was shown and caused the disarragement of enterocytes' cytoskeleton and cell junctions' integrity [35].

Enterotoxigenic E. coli (ETEC) are among the most important agents causing post-weaning diarrhea in pigs. ETEC infection is often manifested as watery diarrhea with decrease of weight and eventually death resulting in serious economic losses. Presence of virulence genes in ETEC differs between neonatal and weaned piglets. In post-weaning piglets (PWD), the most common fimbrial antigens are F4 (K88) and F18 [36, 37]. In our study, we detected $E$. coli with these two fimbrial antigens as well. Fimbriae F4 and F18 are responsible for $E$. coli adhesion to the intestinal epithelium and colonization of the small intestine. The most often enterotoxins in PWD are thermostable toxins STa and STb and thermolabile toxin $[38,39]$. Our study focused on the detection of STa, STb and on Shiga toxin Stx2 that cause hemorrhagic diarrhea. Our results showed presence of Stx 2 only in 4 piglets and none of them was associated with diarrhea. STa and STb were detected mostly in combination with F4, $\mathrm{F} 18$ or as $\mathrm{STa} / \mathrm{STb}$. It is known that fimbrial genes rarely occur without other virulence traits [40]. In our study, only a few $E$. coli isolates were positive for enterotoxins alone. However, the prevalence of $E$. coli with virulence traits varied over time. The majority of isolates positive for virulence genes was found on the day 5 , with the exception of piglets fed $\mathrm{ZnC}$. It is very likely that the piglets at this point were stressed out by weaning as well as environmental and dietary changes which may have led to the increase of ETEC. This was also the time with the highest occurrence of diarrhea correlating with the detection of ETEC. After that, the number of positive isolates decreased in the control and ZnA groups. This indicates that the recovery of normal microbiota in the gut. In piglets in $\mathrm{ZnC}$ and $\mathrm{ZnO}$ groups, we did not observe any significant changes in the number of ETEC over time. As was mentioned above, presence of ETEC does not necessarily leads to diarrhea. This is in agreement with another study, where ETEC were detected in subclinical infections in pigs [41]. Authors showed that numerous ETEC can persist and circulate in a swine population without clinical manifestation of diarrhea or edema disease. This is important for diagnostics and epidemiology and for understanding the dynamics and ecology of ETEC in pigs.

In the control group, half of the pigs got diarrhea by the day 20 which is high occurrence compared to that of the treated groups. This corresponds with the time the gastrointestinal microbiome was expected to stabilize after weaning. However, samples taken from the control group did not have high prevalence of $E$. coli virulence factors which indicates that diarrhea was caused by other factors.

In previous studies, a higher $\mathrm{Zn}$ content in blood serum increased by 6.8 resp. $9.7 \mathrm{mg} / \mathrm{mL}$ in weaned piglets fed 450 or $3000 \mathrm{mg} \mathrm{Zn} / \mathrm{kg}$ diet [12]. In our study, there was an increase in blood $\mathrm{Zn}$ concentration at the dose of $2000 \mathrm{mg} / \mathrm{kg}$ diet. According to results reported by Pei et al. [12], Zn in ZnNPs was mostly deposited in the pancreas, and the majority of $\mathrm{Zn}$ was excreted in the feces. This also in agreement with earlier observations, that showed that linear increase in blood $\mathrm{Zn}$ concentration was observed after adding ZnNPs at 15, 30 or 60 $\mathrm{mg} \mathrm{Zn} / \mathrm{kg}$ of diet for 21 days in weaned piglets but other blood parameters were not affected [42]. In another study, the highest increase of $\mathrm{Zn}$ concentration in blood plasma and pancreas was observed at a dose of $800 \mathrm{mg}$ $\mathrm{ZnNPs} / \mathrm{kg}$ of diet [13]. Using ZnNPs at a dose of 1200 $\mathrm{mg} \mathrm{Zn/kg} \mathrm{diet,} \mathrm{as} \mathrm{in} \mathrm{our} \mathrm{experiment,} \mathrm{a} \mathrm{higher} \mathrm{final}$ weight was observed when compared to that of the control group. Higher concentrations of zinc in plasma and liver were also observed [43].

As seen from our results, it is necessary to focus not only on the dose of ZnNPs, but also on the modification of nanoparticles. In our study, we used phosphates which may, to some extent, limit the absorption of $\mathrm{Zn}$ into the body as also shown in our previous study [11]. At a dose of $2000 \mathrm{mg} \mathrm{kg} /$ diet in the diet of rats, the increase in Zn concentration in the blood, liver, and kidney increased compared to that of the control group, and this depended on the type of NPs modification. Other MDA antioxidant parameters, superoxide dismutase (SOD) and oxidized glutathione concentrations were not affected. In another study, the dose of $10 \mathrm{mg}$ $\mathrm{ZnNPs} / \mathrm{kg}$ of body weight fed to rats for 30 days resulted in higher activity of SOD and GPx in the testicular tissue. In contrast, the MDA level decreased [44]. These results do not entirely correlate with our observation. The antioxidant status of the organism was not 
significantly affected, except in the ZnA group of piglets where we observed significantly higher GPx activity at the 500, 1000 and $2000 \mathrm{mg} / \mathrm{kg}$ diet. ZnNPs were tested in vitro using the antioxidant method of 2,2-diphenyl-1picrylhydrazyl (DPPH), which showed higher efficacy compared to that of the control group and $\mathrm{ZnO}$ [45]. Also, Gupta et al. observed a higher antioxidant effect of ZnNPs under in vitro conditions using the DPPH assay and Free Radical Scavenging Activities (FRSA) [46]. In contrast to our experiment, these results were obtained under in vitro conditions. Also, the form and modifications of ZnNPs were different from those used in our study. In the long-term study (270 days) on mice, the oxidative stress generation by $\mathrm{Zn}$ ions and $\mathrm{ZnO}$ NPs treatment was not shown. The levels of GSH and MDA in the liver and the lungs did not change compared to that of control. Furthermore, the fecal analysis showed two times higher $\mathrm{Zn}$ concentration than that in the control group indicating the main route of $\mathrm{Zn}$ excretion [47].

In a previous study, piglets fed by nanozinc $(1200 \mathrm{mg} /$ $\mathrm{kg}$ diet) showed increased crypt depth, villus length and villus surface area in the ileum and the duodenum compared to that of control (Zn $100 \mathrm{mg} / \mathrm{kg}$ diet) [43]. Similar results were obtained in the study of Wang et al. [13], where after supplementation of ZnNPs in the piglet's diet they observed higher villous height (by $30.9 \mu \mathrm{m}$ ), crypt depth (by $20.2 \mu \mathrm{m}$ ), villous width (by $18.3 \mu \mathrm{m}$ ) and villous surface compared to that of the control group. The addition of $2500 \mathrm{mg} / \mathrm{kg}$ diet of $\mathrm{ZnO}$ increased the length of the villus height in the jejunum and the ileum by 23 and $22 \mu \mathrm{m}$, respectively, compared to that of control receiving $120 \mathrm{mg}$ zinc per $\mathrm{kg}$ diet [48]. In our experiment, malabsorption syndrome was diagnosed in the control group and also in the group supplemented by $\mathrm{ZnA} 2000 \mathrm{mg} / \mathrm{kg}$. This could be due to the combination of the higher zinc dose and the form of ZnNPs based on the hydrogen phosphate precursor. Malabsorption syndrome refers to a number of disorders in which the small intestine cannot absorb enough nutrients and fluids. Nutrients that the small intestine often has trouble absorbing can include macronutrients (proteins, carbohydrates, and fats), micronutrients (vitamins and minerals) or both. Inadequate levels of these nutrients can cause imbalance of antioxidant systems in the body [49]. In the control group of piglets, where the malabsobtion syndrome was found, no zinc blood imbalance was detected. Also, GPx activity and MDA concentrations were not affected in this group. Other studies suggest that the high doses of zinc $(2500 \mathrm{mg} / \mathrm{kg}$ diet $)$ also affect the enzyme levels in the liver (e.g. arginase1, thiosulfate sulfurtransferase, HSP70), thus supporting the hypothesis of intermediary effects of pharmacological levels of zinc oxide fed to pigs [50]. $\mathrm{ZnA}$ and $\mathrm{ZnC}$ nanoparticles were tested in a previous in vivo experiment and did not show acute toxicity [11].

Due to the forthcoming ban of high pharmacological doses of zinc in the European Union, the efforts are to find alternatives to high-doses of dietary $\mathrm{ZnO}$ in pig productions. The dietary supplementation with the low dose ( $500 \mathrm{mg} / \mathrm{kg}$ of diet) of porous $\mathrm{Zn}$ and $\mathrm{ZnO}$ NPs showed similar or even greater effects on weight gain, intestinal morphology, diarrhea occurrence, and intestine iflamation in piglets compared to that of the high pharmacological dose $(3000 \mathrm{mg} / \mathrm{kg}$ of diet) of $\mathrm{ZnO}$ [51]. Analogously, the dose $600 \mathrm{mg} \mathrm{Zn/kg}$ of diet of Zn NPs improved piglets growth performance and reduced diarrhea incidence which is comparable to the high dose of $\mathrm{ZnO}(2000 \mathrm{mg}$ $\mathrm{Zn} / \mathrm{kg}$ ). The presumed mechanism is intestinal microbiota alteration and inflammation response improvement [52]. However, the fate of the excreted nanoparticles and their effect on the environment remain to be investigated. Clearly, the bioavailability and the toxicity depend on characteristics of different nanoparticles [53-55] and how they interact with the organic matter in the soil [56].

\section{Conclusion}

Two formulations of $\mathrm{Zn}$ phosphate-based NPs were tested as alternatives to $\mathrm{ZnO}$, which is traditionaly used as a dietary supplement in livestock productions. The extensive use of high-dose dietary $\mathrm{ZnO}$ may result in a long-term adverse effect on the environment, therefore the application of lower-doses ZnNPs with the same effect on swine production could be a potential solution. We demonstrate that dietary supplementations with ZnA NPs significantly increased piglet weight gain even at the lowest concentration $(500 \mathrm{mg} / \mathrm{kg})$ without any serious side effects on the piglets. In contrast, the highest $\mathrm{ZnO}$ dose $(2000 \mathrm{mg} / \mathrm{kg})$ did not have a such effect. Our results indicate that NPs are a promising alternative to high pharmacological doses of conventional $\mathrm{ZnO}$.

\section{Supplementary information}

Supplementary information accompanies this paper at https://doi.org/10. 1186/s40104-020-00458-X.

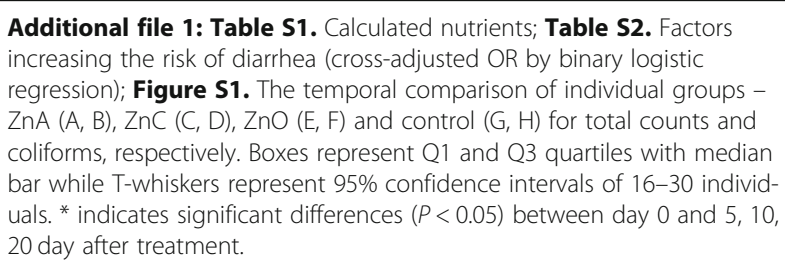

\section{Abbreviations}

ANOVA: Analysis of variance; CFU: Colony forming unit; Cl: Confidence interval; DPPH: 2,2-diphenyl-1-picrylhydrazyl; ETEC: Enterotoxigenic E. coli; FRSA: Free radical scavenging activities; GPx: Glutathione peroxidase; GSH: Glutathione; GSSG: Glutathione disulfide; MALDI-TOF MS: Matrix-assisted laser desorption/ionization time-of-flight mass spectrometry; 
MDA: Malondialdehyde; NADPH: Nicotinamide adenine dinucleotide phosphate; NPs: Nanoparticles; OR: Odds ratio; PCA: Plate count agar; PWD: Post-weaning piglets; ROS: Reactive oxygen species; SOD: Superoxide dismutase; TBA: Thiobarbituric acid; WG: Weight gain; ZnNPs: Zinc nanoparticles; ZnO: Zinc oxide

\section{Acknowledgements}

Authors thank Prof. A. Cizek from the University of Veterinary and Pharmaceutical Sciences, Brno for allowing us to use the MALDI-TOF analyzer and Drs. I. Kolackova and R. Karpiskova from the Veterinary Research Institute, Brno for providing us with E. coli strains as positive controls.

\section{Authors' contributions}

$\mathrm{PH}$ and $\mathrm{KS}$ designed the experiments. PK synthesized and characterized the nanoparticles. SK, KD, and LB performed the microbiological analyses and $P C R$. DB, EV, and JB realized the animal experiments. SS and PN worked on oxidative status and zinc levels determination. TD and OZ performed the MS analysis. YH analyzed data. JS, LZ and VA edited the manuscript. KS, LZ, KD, $\mathrm{LB}$ and $\mathrm{PH}$ wrote the manuscript. All authors read and approved the final manuscript.

\section{Funding}

Financial support from NAZV QK1720349 "Nanoparticles zinc as an alternative to antibiotics in pigs" and ERDF "Multidisciplinary research to increase application potential of nanomaterials in agricultural practice" (No. CZ.02.1.01/0.0/0.0/16_025/0007314) is gratefully acknowledged. This study was also supported by Internal Grant Agency of Mendel University in Brno (AF-IGA2019-TP006) and by CEITEC 2020 (LQ1601).

\section{Availability of data and materials}

All data generated or analysed during this study are included in this published article [and its supplementary information files].

\section{Ethics approval and consent to participate}

The experiments were performed with the approval of the Ethics Committee at the Faculty of AgriSciences, Mendel University in Brno, Czech Republic in accordance with Act No. 246/1992 Coll. on the protection of animals against cruelty.

\section{Consent for publication}

Not applicable.

\section{Competing interests}

The authors declare that they have no competing interests.

\section{Author details}

${ }^{1}$ Department of Chemistry and Biochemistry, Mendel University in Brno, Zemedelska 1, CZ-613 00 Brno, Czech Republic. ${ }^{2}$ Central European Institute of Technology, Brno University of Technology, Purkynova 123, CZ-612 00 Brno, Czech Republic. ${ }^{3}$ Department of Animal Nutrition and Forage Production, Mendel University in Brno, Zemedelska 1, CZ-613 00 Brno, Czech Republic. ${ }^{4}$ Institute of Animal Science, Pratelstvi 815, CZ-104 00 Praha Uhrineves, Czech Republic. ${ }^{5}$ Department of Animal Breeding, Mendel University in Brno, Zemedelska 1, CZ-613 00 Brno, Czech Republic. ${ }^{6}$ Department of Inorganic Chemistry, Faculty of Science, Palacky University, 17. listopadu 12, CZ-771 46 Olomouc, Czech Republic. ${ }^{7}$ Central European Institute of Technology, Center for Zoonoses, University of Veterinary and Pharmaceutical Sciences, Brno, Palackeho 1946/1, CZ-612 42 Brno, Czech Republic.

Received: 15 January 2020 Accepted: 8 April 2020

Published online: 09 June 2020

\section{References}

1. Poulsen HD. Zinc oxide for weanling piglets. Acta Agric Scand Sect A-Anim Sci. 1995;45(3):159-67.

2. Hu CH, Song J, You ZT, Luan ZS, Li WF. Zinc oxide-Montmorillonite hybrid influences diarrhea, intestinal mucosal integrity, and digestive enzyme activity in weaned pigs. Biol Trace Elem Res. 2012;149(2):190-6.
3. SCVMP. Standing Committee on Veterinary Medicinal Products (SCVMP): Summary report of the 19 June 2017 of the Standing Committee on Veterinary Medicinal Products. 2017.

4. EMA. European Medicines Agency (EMA): Committee for Medicinal Products for Veterinary Use (CVMP); Article 35. 2017.

5. NRC. National Research Council 2012: Nutrient requirements of swine: eleventh revised edition. Washington, DC: The National Academies Press; 2012

6. Chi F, Johnston S, Tang X, Chen W, Wang B, Tang S. Effects of replacing zinc oxide and antibiotics with NeoPrime (R) on growth performance and plasma and fecal endotoxin concentration in nursery pigs. J Anim Sci. 2018; 96:321.

7. Lei XJ, Kim H. Low dose of coated zinc oxide is as effective as pharmacological zinc oxide in promoting growth performance, reducing fecal scores, and improving nutrient digestibility and intestinal morphology in weaned pigs. Anim Feed Sci Technol. 2018;245:117-25.

8. Jensen J, Larsen MM, Bak J. National monitoring study in Denmark finds increased and critical levels of copper and zinc in arable soils fertilized with pig slurry. Environ Pollut. 2016;214:334-40.

9. Bednorz C, Oelgeschlager K, Kinnemann B, Hartmann S, Neumann K, Pieper $R$, et al. The broader context of antibiotic resistance: zinc feed supplementation of piglets increases the proportion of multi-resistant Escherichia coli in vivo. Int J Med Microbiol. 2013;303(6-7):396-403.

10. Rensing C, Moodley A, Cavaco LM, McDevitt SF. Resistance to metals used in agricultural production. Microbiol Spectr. 2018;6(2):24.

11. Horky P, Skalickova S, Urbankova L, Baholet D, Kociova S, Bytesnikova Z, et al. Zinc phosphate-based nanoparticles as a novel antibacterial agent: in vivo study on rats after dietary exposure. J Anim Sci Biotechnol. 2019;10:17.

12. Pei $X$, Xiao ZP, Liu LJ, Wang G, Tao WJ, Wang MQ, et al. Effects of dietary zinc oxide nanoparticles supplementation on growth performance, zinc status, intestinal morphology, microflora population, and immune response in weaned pigs. J Sci Food Agric. 2019;99(3):1366-74.

13. Wang $C$, Zhang LG, Ying ZX, He JT, Zhou L, Zhang LL, et al. Effects of dietary zinc oxide nanoparticles on growth, diarrhea, mineral deposition, intestinal morphology, and barrier of weaned piglets. Biol Trace Elem Res. 2018;185(2):364-74.

14. Jarvis TA, Miller RJ, Lenihan HS, Bielmyer GK. Toxicity of ZnO nanoparticles to the copepod Acartia tonsa, exposed through a phytoplankton diet. Environ Toxicol Chem. 2013;32(6):1264-9.

15. Horky P, Skladanka J, Nevrkla P, Slama P. Effect of diet supplemented with antioxidants (selenium, copper, vitamins e and C) on antioxidant status and ejaculate quality of breeding boars. Ann Anim Sci. 2016;16(2):521-32.

16. Jancikova $P$, Horky $P$, Zeman $L$. The effect of feed additive containing vitamins and trace elements on the elements profile and growth of skin derivatives in horses. Ann Anim Sci. 2012;12(3):381-91.

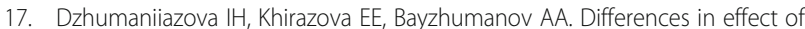
intermittent fasting on autonomic nervous system balance and antioxidant content in female and male Wistar rats. Acta Physiol. 2019;227:56.

18. Desai VG, Aidoo A, Li J, Lyn-Cook LE, Casciano DA, Feuers RJ. Effects of bleomycin on liver antioxidant enzymes and the electron transport system from ad libitum-fed and dietary-restricted female and male Fischer 344 rats. Nutr Cancer. 2000;36(1):42-51.

19. Mennecozzi M, Landesmann B, Palosaari T, Harris G, Whelan M. Sex differences in liver toxicity-do female and male human primary hepatocytes react differently to toxicants In Vitro? PLoS One. 2015;10(4):e0122786.

20. Zurek L, Schal C. Evaluation of the German cockroach (Blattella germanica) as a vector for verotoxigenic Escherichia coli F18 in confined swine production. Vet Microbiol. 2004;101(4):263-7.

21. Lee SI, Kang SG, Kang ML, Yoo HS. Development of multiplex polymerase chain reaction assays for detecting enterotoxigenic Escherichia coli and their application to field isolates from piglets with diarrhea. J Vet Diagn Investig. 2008;20(4):492-6.

22. Meng JH, Zhao SH, Doyle MP. Virulence genes of Shiga toxin-producing Escherichia coli isolated from food, animals and humans. Int J Food Microbiol. 1998:45(3):229-35.

23. Bej AK, Mahbubani MH, Dicesare $J$, Atlas RM. Polymerase chain reactiongene probe detection of microorganisms by using filter-concentrated samples. Appl Environ Microbiol. 1991;57(12):3529-34.

24. Barszcz M, Taciak M, Tusino A, Cobanova K, Gresakova L. The effect of organic and inorganic zinc source, used in combination with potato fiber, 
on growth, nutrient digestibility and biochemical blood profile in growing pigs. Livest Sci. 2019;227:37-43.

25. Zhao CY, Tan SX, Xiao XY, Qiu XS, Pan JQ, Tang ZX. Effects of dietary zinc oxide nanoparticles on growth performance and Antioxidative status in broilers. Biol Trace Elem Res. 2014;160(3):361-7.

26. Wang W, Van Noten N, Degroote J, Romeo A, Vermeir P, Michiels J. Effect of zinc oxide sources and dosages on gut microbiota and integrity of weaned piglets. J Anim Physiol Anim Nutr. 2019;103(1):231-41.

27. Fernandes $C D$, Resende $M$, Rodrigues $L M$, Garbossa CAP, Costa $L B$, Ferreira RA, et al. Dietary fiber and zinc additives on performance and intestinal health of Escherichia coli challenged piglets. Sci Agric. 2020;77(2):1-7.

28. Davin R, Manzanilla EG, Klasing KC, Perez JF. Effect of weaning and in-feed high doses of zinc oxide on zinc levels in different body compartments of piglets. J Anim Physiol Anim Nutr. 2013;97:6-12.

29. Li Y, Guo Y, Wen ZS, Jiang XM, Ma X, Han XY. Weaning stress perturbs gut microbiome and its metabolic profile in piglets. Sci Rep. 2018;8:12.

30. Ding XH, Lan WS, Liu G, Ni HJ, Gu JD. Exploring possible associations of the intestine bacterial microbiome with the pre-weaned weight gaining performance of piglets in intensive pig production. Sci Rep. 2019;9:10.

31. Pedersen RM, Gronnemose RB, Staerk K, Asferg CA, Andersen TB, Kolmos HJ, et al. A method for quantification of epithelium colonization capacity by pathogenic Bacteria. Front Cell Infect Microbiol. 2018;8:15.

32. Otto M. Physical stress and bacterial colonization. FEMS Microbiol Rev. 2014; 38(6):1250-70.

33. Jacobson M, Hård af Segerstad C, Gunnarsson A, Fellstrom C, Klingenberg $K D$, Wallgren $P$, et al. Diarrhoea in the growing pig - a comparison of clinical, morphological and microbial findings between animals from good and poor performance herds. Res Vet Sci. 2003;74(2):163-9.

34. Colombo G, Cortinovis C, Moschini E, Bellitto N, Perego MC, Albonico M, et al. Cytotoxic and proinflammatory responses induced by $\mathrm{ZnO}$ nanoparticles in in vitro intestinal barrier. J Appl Toxicol. 2019;39(8):1155-63.

35. Bacchetta R, Moschini E, Santo N, Fascio U, Del Giacco L, Freddi S, et al. Evidence and uptake routes for zinc oxide nanoparticles through the gastrointestinal barrier in Xenopus laevis. Nanotoxicology. 2014;8(7):728-44.

36. Dubreuil JD, Isaacson RE, Schifferli DM. Animal Enterotoxigenic Escherichia coli. EcoSal Plus. 2016;7(1):1-47.

37. Fairbrother JM, Nadeau E, Gyles CL. Escherichia coli in postweaning diarrhea in pigs: an update on bacterial types, pathogenesis, and prevention strategies. Anim Health Res Rev. 2005;6(1):17-39.

38. Soderlind O, Mollby R. Enterotoxins, O-groups, and K88 antigen in Escherichia coli from neonatal piglets with and without diarrhea. Infect Immun. 1979;24(3):611-6.

39. Wilson RA, Francis DH. Fimbriae and enterotoxins associated with Escherichia coli serogroups isolated from pigs with colibacillosis. Am J Vet Res. 1986;47(2):213-7.

40. Zhang WP, Zhao MJ, Ruesch L, Omot A, Francis D. Prevalence of virulence genes in Escherichia coli strains recently isolated from young pigs with diarrhea in the US. Vet Microbiol. 2007;123(1-3):145-52.

41. Moredo FA, Pineyro PE, Marquez GC, Sanz M, Colello R, Etcheverria A, et al. Enterotoxigenic Escherichia coli subclinical infection in pigs: bacteriological and genotypic characterization and antimicrobial resistance profiles. Foodborne Pathog Dis. 2015;12(8):704-11.

42. Milani NC, Sbardella M, Ikeda NY, Arno A, Mascarenhas BC, Miyada VS. Dietary zinc oxide nanoparticles as growth promoter for weanling pigs. Anim Feed Sci Technol. 2017;227:13-23.

43. Wang C, Zhang LG, Su WP, Ying ZX, He JT, Zhang LL, et al. Zinc oxide nanoparticles as a substitute for zinc oxide or colistin sulfate: Effects on growth, serum enzymes, zinc deposition, intestinal morphology and epithelial barrier in weaned piglets. PLoS One. 2017:12(7):1-14

44. Afifi M, Almaghrabi OA, Kadasa NM. Ameliorative effect of zinc oxide nanoparticles on antioxidants and sperm characteristics in streptozotocininduced diabetic rat testes. Biomed Res Int. 2015;2015:1-6.

45. Bharathi D, Bhuvaneshwari V. Synthesis of zinc oxide nanoparticles ( $\mathrm{nnO}$ NPs) using pure bioflavonoid rutin and their biomedical applications: antibacterial, antioxidant and cytotoxic activities. Res Chem Intermed. 2019; 45(4):2065-78.

46. Gupta R, Malik P, Das N, Singh M. Antioxidant and physicochemical study of Psidium guajava prepared zinc oxide nanoparticles. J Mol Liq 2019;275:749-67.
47. Liu JH, Ma X, Xu YY, Tang H, Yang ST, Yang YF, et al. Low toxicity and accumulation of zinc oxide nanoparticles in mice after 270-day consecutive dietary supplementation. Toxicol Res. 2017;6(2):134-43.

48. Hosseindoust AR, Lee SH, Kim JS, Choi YH, Noh HS, Lee JH, et al. Dietary bacteriophages as an alternative for zinc oxide or organic acids to control diarrhoea and improve the performance of weanling piglets. Vet Med. 2017; 62(2):53-61.

49. Kanikowska A, Wlochal M, Mielcarz G, Grzymislawski M, Kucharski M. Evaluation of zinc and copper concentrations and the total antioxidant capacity of blood plasma in patients with malabsorption syndrome. J Elem. 2015;20(4):873-85.

50. Bondzio A, Pieper R, Gabler C, Weise C, Schulze P, Zentek J, et al. Feeding low or pharmacological concentrations of zinc oxide changes the hepatic proteome profiles in Weaned Piglets. PLoS One. 2013;8(11):1-11.

51. Long LN, Chen JS, Zhang YG, Liang X, Ni HJ, Zhang B, et al. Comparison of porous and nano zinc oxide for replacing high-dose dietary regular zinc oxide in weaning piglets. PLoS One. 2017;12(8):14.

52. Xia T, Lai WQ, Han MM, Han M, Ma X, Zhang LY. Dietary ZnO nanoparticles alters intestinal microbiota and inflammation response in weaned piglets. Oncotarget. 2017:8(39):64878-91.

53. Garcia-Gomez C, Garcia S, Obrador A, Almendros P, Gonzalez D, Fernandez MD. Effect of ageing of bare and coated nanoparticles of zinc oxide applied to soil on the $\mathrm{Zn}$ behaviour and toxicity to fish cells due to transfer from soil to water bodies. Sci Total Environ. 2020;706:1-11.

54. Ameen F, AlYahya S, Govarthanan M, Aljahdali N, Al-Enazi N, Alsamhary K, et al. Soil bacteria Cupriavidus sp. mediates the extracellular synthesis of antibacterial silver nanoparticles. J Mol Struct. 2020;1202:1-6.

55. Zheng M, Huang Z, Ji HD, Qiu FG, Zhao DY, Bredar ARC, et al. Simultaneous control of soil erosion and arsenic leaching at disturbed land using polyacrylamide modified magnetite nanoparticles. Sci Total Environ. 2020; 702:1-9.

56. Josko I. Copper and zinc fractionation in soils treated with $\mathrm{CuO}$ and $\mathrm{ZnO}$ nanoparticles: the effect of soil type and moisture content. Sci Total Environ. 2019;653:822-32.

\section{Ready to submit your research? Choose BMC and benefit from:}

- fast, convenient online submission

- thorough peer review by experienced researchers in your field

- rapid publication on acceptance

- support for research data, including large and complex data types

- gold Open Access which fosters wider collaboration and increased citations

- maximum visibility for your research: over $100 \mathrm{M}$ website views per year

At BMC, research is always in progress.

Learn more biomedcentral.com/submissions 